\title{
Fecundity of Sebastes mentella and Sebastes norvegicus in the Irminger Sea and Icelandic waters
}

\section{Fecundidad de Sebastes mentella y Sebastes norvegicus en el mar de Irminger y aguas de Islandia}

\author{
Fran Saborido-Rey ${ }^{1 *}$, Rosario Domínguez-Petit ${ }^{1}$, Dolores Garabana² ${ }^{2}$ Porsteinn Sigurðsson ${ }^{3}$ \\ ${ }^{1}$ Institute of Marine Research-Consejo Superior de Investigaciones Científicas (IIM-CSIC), Eduardo \\ Cabello 6, 36208 Vigo, Spain \\ 2 Instituto Español de Oceanografía, Paseo Alcalde Francisco Vázquez 10, 15001 A Coruña, Spain \\ ${ }_{3}$ Marine Research Institute, Skulagata 4, 101 Reykjavik, Iceland \\ * Corresponding author. E-mail: fran@iim.csic.es
}

\begin{abstract}
Fecundity of redfish Sebastes mentella and Sebastes norvegicus in the Irminger Sea and Icelandic waters was analyzed in relation to several maternal features and oocyte developmental stages. The mean potential fecundity in $S$. norvegicus was estimated to be 123,300 oocytes and relative fecundity averaged 116 oocytes $\mathrm{g}^{-1}$. Mean potential fecundity in $S$. mentella was 50,013 oocytes and relative fecundity was 64 oocytes $\mathrm{g}^{-1}$. Strong fecundity down-regulation (50\% on average) was observed during oocyte development estimated from September to November, when oocytes reached the advanced stage of vitellogenesis. This result implies that fecundity can only be comparable between individuals presenting the same stage of oocyte development. However, the development rates differed between species and between stocks, and therefore the same stage is reached at a different time of the year. Fecundity varied significantly with female weight and length, while condition had little influence on fecundity variation.
\end{abstract}

Key words: Sebastes mentella, Sebastes norvegicus, Irminger Sea, Iceland, fecundity.

RESUMEN. La fecundidad de la gallineta nórdica, Sebastes mentella y Sebastes norvegicus, en el mar de Irminger y aguas de Islandia se analizó en relación con diversas características maternales y durante diferentes periodos del desarrollo ovocitario. La fecundidad potencial de S. norvegicus se estimó en 123,300 ovocitos con una fecundidad relativa de 116 ovocitos $\mathrm{g}^{-1}$. La fecundidad potencial promedio de $S$. mentella fue de 50,013 ovocitos con una fecundidad relativa de 64 ovocitos $\mathrm{g}^{-1}$. Sin embargo, se observó una fuerte regulación decreciente de la fecundidad (un promedio del 50\%) durante el desarrollo ovocitario estimado entre septiembre y noviembre, cuando los ovocitos alcanzaron la vitelogénesis avanzada. Este descenso implica que la fecundidad sólo se pueda comparar entre individuos que se encuentren en el mismo estado de desarrollo ovocítico. Sin embargo, la tasa de desarrollo ovocitario fue diferente para cada especie y población, y por tanto el mismo estado se alcanza en diferentes momentos del año. La fecundidad varió significativamente con la talla y el peso de la hembra, mientras que la condición tuvo poca influencia en la variabilidad de la fecundidad.

Palabras clave: Sebastes mentella, Sebastes norvegicus, mar de Irminger, Islandia, fecundidad.

\section{INTRODUCTION}

Redfish are widely distributed across the whole North Atlantic. In the central North Atlantic (ICES Divisions V, VI, XII, and XIV; fig. 1) there are three species of redfish: Sebastes norvegicus (formerly known as Sebastes marinus, see Kendall 2000), Sebastes mentella, and Sebastes viviparus. The first two are subject to important fisheries in the area, while $S$. viviparus is of minor commercial value in Icelandic waters. Sebastes mentella and S. norvegicus were fished, historically, on the shelves and banks of the Faroe Islands, Iceland, and East Greenland (Björnsson and Sigurdsson 2003). The start of a new pelagic S. mentella fishery in the Irminger Sea in 1982 resulted in the organization of a large-scale directed international fishery in the area (Sigurdsson et al. 2006).

\section{INTRODUCCIÓN}

La gallineta nórdica se distribuye a lo largo del Atlántico Norte. En la parte central del Atlántico Norte (Divisiones ICES V, VI, XII y XIV; fig. 1) se encuentran tres especies de la gallineta nórdica: Sebastes norvegicus (antes conocida como Sebastes marinus, ver Kendall 2000), Sebastes mentella y Sebastes viviparus. Las primeras dos son especies de importancia pesquera en la zona, mientras que S. viviparus es de menor valor comercial en aguas islándicas. Históricamente, S. mentella y S. norvegicus han sido capturadas en las plataformas y los bancos de las islas Feroe, Islandia y Groenlandia oriental (Björnsson y Sigurdsson 2003). El comienzo de una nueva pesquería pelágica dirigida a S. mentella en el mar de Irminger en 1982 condujo a la 
The golden redfish, S. norvegicus, in ICES Subareas V and XIV is considered as one management unit. However, considerable difficulties were encountered when defining the stock structure of S. mentella (Saborido-Rey et al. 2004). The "Workshop on Redfish Stock Structure" (ICES 2009) reviewed the stock structure of $S$. mentella and concluded that there are three biological stocks of this species in the Irminger Sea and adjacent waters: a "Deep Pelagic" stock, a "Shallow Pelagic" stock, and an "Icelandic Slope" stock.

All Sebastes species are viviparous (i.e., the eggs are fertilized internally), and spawning is characterized by the parturition or extrusion of 40,000 to 400,000 pelagic larvae annually (Magnússon and Magnússon 1995). In redfish, viviparity is lecitotrophic (i.e., embryos are nourished by yolk; Wourms 1981). Thus, although embryos develop within the ovary their development is at the expense of previously accumulated yolk. Oocyte development in S. mentella and $S$. norvegicus is group-synchronous with a long vitellogenic period that extends from early summer to mid-winter when ovulation and fertilization occur (Saborido-Rey 1994). Embryogenesis lasts for one month (Sorokin 1961) and parturition occurs between March and April depending on the considered area (Sorokin 1961; Magnússon 1980, 1983; Saborido-Rey 1994). Oocyte recruitment in redfish is determinate (Murua and Saborido-Rey 2003), meaning that at the time of ovulation the full stock of vitellogenic oocytes is recruited (i.e., the number of oocytes that potentially will be ovulated during the breeding season [potential fecundity] is determined prior to ovulation). However, not all the potential fecundity develops into eggs (realized fecundity) and follicular atresia may account for a substantial part of the fecundity in a process referred to as down-regulation (Óskarsson et al. 2002), often seen as a process to match the energy availability of the fish (Kurita et al. 2003).

Studies of fecundity in North Atlantic Sebastes have been quite limited, with some work carried out a long time ago on S. norvegicus (Corlett 1964, Raitt and Hall 1967) and on S. mentella (St. Pierre and de Lafontaine 1995, Drevetnyak and Gusev 1996). In the Irminger Sea, fecundity of $S$. mentella has been studied only by Jones (1969). Studies on fecundity are essential to understanding stock reproductive potential (Tomkiewicz et al. 2003, Saborido-Rey and Trippel 2013). Improving knowledge of fecundity dynamics and the causes of its variation is essential when estimating egg production, the main link between spawning stock and recruitment. While the biomass of $S$. norvegicus is at high levels (ICES 2014), the biomass of S. mentella has decreased in the last decade to its lowest historical level and there have been no signals of recruitment (ICES 2014). Fecundity dynamics is therefore a key factor to understand stock dynamics and to provide biological information for improving stock assessment.

In this paper, fecundity is analyzed in S. mentella and $S$. norvegicus in the Irminger Sea and Icelandic waters with special emphasis on their relation to several maternal features organización de una pesquería internacional dirigida de gran escala en la región (Sigurdsson et al. 2006).

En las subáreas ICES V y XIV, la gallineta nórdica dorada, S. norvegicus, es considerada como una unidad de gestión. En el caso de $S$. mentella, sin embargo, surgían dificultades para definir su estructura poblacional (Saborido-Rey et al. 2004), por lo que en un taller sobre la gallineta nórdica ("Workshop on Redfish Stock Structure", ICES 2009) se revisó la estructura poblacional de esta especie y se concluyó que existían tres poblaciones biológicas de $S$. mentella en el mar de Irminger y aguas adyacentes: una población pelágica, una población somera y una población del talud de Islandia.

Todas las especies del género Sebastes son vivíparas (i.e., los huevos son fertilizados internamente), y el desove se caracteriza por la puesta o extrusión de 40,000 a 400,000 larvas pelágicas anualmente (Magnússon y Magnússon 1995). En la gallineta nórdica, la viviparidad es lecitotrófica (i.e., los embriones son nutridos por la yema del huevo; Wourms 1981). Así, aunque los embriones se desarrollan dentro del ovario, su desarrollo sucede a expensas de la yema acumulada previamente. El desarrollo de los ovocitos en S. mentella y $S$. norvegicus es de tipo sincrónico por grupos, con un periodo vitelogénico largo que se extiende desde principios del verano hasta mediados del invierno cuando ocurren la ovulación y fertilización (Saborido-Rey 1994). La embriogénesis dura un mes (Sorokin 1961) y la puesta sucede entre marzo y abril según el área considerada (Sorokin 1961; Magnússon 1980, 1983; Saborido-Rey 1994). El reclutamiento de ovocitos es de tipo determinado (Murua y Saborido-Rey 2003), esto es, todos los ovocitos están reclutados al momento de iniciar la ovulación (i.e., el número de ovocitos que potencialmente serán ovulados durante la época de reproducción [fecundidad potencial] se determina antes de la ovulación); sin embargo, no toda la fecundidad potencial produce huevos (fecundidad realizada) y la atresia folicular puede explicar una parte substancial de la fecundidad en un proceso conocido como regulación decreciente (Óskarsson et al. 2002), frecuentemente visto como un proceso para balancear la disponibilidad energética del pez (Kurita et al. 2003).

Existen pocos estudios de la fecundidad en peces del género Sebastes del Atlántico Norte, entre ellos unos realizados hace bastante tiempo sobre S. norvegicus (Corlett 1964, Raitt y Hall 1967) y sobre S. mentella (St. Pierre y de Lafontaine 1995, Drevetnyak y Gusev 1996). En el mar de Irminger, sólo Jones (1969) ha estudiado la fecundidad de $S$. mentella. Los estudios de fecundidad son esenciales para entender el potencial reproductivo de las poblaciones de peces (Tomkiewicz et al. 2003, Saborido-Rey y Trippel 2013). Un mejor conocimiento de la dinámica de fecundidad y las causas de su variación es importante en la estimación de la producción de huevos, el enlace principal entre la población desovante y el reclutamiento. Mientras que la biomasa de $S$. norvegicus se mantiene en niveles altos (ICES 2014), en la última década la biomasa de $S$. mentella se ha visto reducida a su menor nivel histórico y no hay señales de 
and fecundity down-regulation. Comparisons of relative fecundity between species and between stocks are made.

\section{MATERIALS AND METHODS}

A total of 148 ovaries from mature female S. mentella and $S$. norvegicus were collected during commercial fishing surveys conducted in the Irminger Sea and off Iceland (fig. 1, table 1) using pelagic and bottom trawls (Sigurdsson et al. 2006). For each fish, total length, round weight, and gutted weight were recorded at sea.

\section{Histology and ovarian development staging}

The ovaries were preserved in a $3.6 \%$ solution of phosphate buffered formaldehyde and stored for at least six months before measurements. Ovary sections of $0.5 \mathrm{~cm}$ from the central portion of the gonad were embedded in paraffin based on conventional histological processing and $3-\mu \mathrm{m}$ sections were cut and stained with hematoxylin and eosin. Histology was used to determine the ovarian developmental phase based on the vitellogenic stages observed. To achieve this, vitellogenesis was divided into nine stages, between vit 1 (early vitellogenesis) and vit9 (late vitellogenesis).

All samples were histologically screened in order to assess the presence of massive atresia, a mechanism by which the ovary undergoes a mass reabsorption of yolked oocytes and individuals fail to spawn during a reproductive season (i.e., skipped spawning; Rideout and Tomkiewicz 2011). Failure to recognize mass oocyte atresia would affect the estimation of fecundity. Some authors have considered the presence of massive atresia when more than $50 \%$ of vitellogenic oocytes are affected (Kurita et al. 2003). However, a more conservative approach was taken and an ovary was considered to be undergoing massive atresia when more than $20 \%$ of the developed oocytes were atretic. For this purpose the normal vitellogenic oocytes and atretic follicles were counted in the whole section. Individuals showing massive atresia were not considered for fecundity estimation.

\section{Fecundity analysis}

Fecundity was determined using the gravimetric method (Bagenal and Braum 1978) in the same individuals on which histology was performed. All individuals were in the developing phase, showing vitellogenic oocytes but no signs of ovulation (presence of postovulatory follicles and/or larvae). The ovary weight after fixation was recorded at the laboratory with a precision of $0.01 \mathrm{~g}$ and subsamples of about $250 \mathrm{mg}$ were taken from a central ovary section. Oocytes were separated from connective tissues using a washing process (modified from Lowerre-Barbieri and Barbieri 1993) and separated by size through sieving. The cortical alveoli follicle diameter, measured in histological sections, defined the minimum mesh size of the sieves. Before they were reclutamiento (ICES 2014). Por lo tanto, la dinámica de fecundidad es un factor clave para entender la dinámica poblacional y proporcionar información biológica para mejorar la evaluación de las poblaciones de peces.

En el presente trabajo, la fecundidad de S. mentella y S. norvegicus en el mar de Irminger y aguas islándicas se analiza en relación a diversas características maternales y la regulación decreciente de la fecundidad. Así mismo, se realizan comparaciones de la fecundidad relativa entre especies y poblaciones.

\section{MATERIALES Y MÉTODOS}

Se recolectaron un total de 148 ovarios de hembras maduras de $S$. mentella y $S$. norvegicus durante muestreos de la pesca comercial en el mar de Irminger y aguas islándicas (fig. 1, tabla 1) con redes de arrastre de fondo y pelágicas (Sigurdsson et al. 2006). La longitud total así como el peso total y eviscerado de cada ejemplar se registraron a bordo.

\section{Histología y desarrollo ovárico}

Los ovarios se preservaron en una solución de formaldehído al 3.6\% tamponado con fosfato y se almacenaron durante al menos seis meses antes de ser analizados. Se incluyeron en parafina secciones de $0.5 \mathrm{~cm}$ de la porción central de la gónada siguiendo técnicas histológicas convencionales, y se cortaron secciones de $3 \mu \mathrm{m}$ que se tiñieron con hematoxilina y eosina. La histología se usó para determinar la fase de desarrollo ovárico con base en los estados vitelogénicos observados. Para esto, la vitelogénesis se dividió en nueve estados, entre vit1 (vitelogénesis temprana) y vit9 (vitelogénesis avanzada).

Todas las muestras fueron examinadas histológicamente para evaluar la presencia de atresia masiva, un mecanismo mediante el cual el ovario reabsorbe masivamente los ovocitos vitelados y los individuos no desovan durante un ciclo reproductivo (skipped spawning, Rideout y Tomkiewicz 2011). Si no se comprueba la presencia de ovocitos atrésicos podría resultar afectada la estimación de la fecundidad. Algunos autores consideran que existe atresia masiva cuando más del $50 \%$ de los ovocitos vitelogénicos resultan afectados (Kurita et al. 2003). Aquí se optó por un enfoque más conservador y se consideró que un ovario presentaba atresia masiva cuando más del $20 \%$ de los ovocitos eran atrésicos. Por lo tanto, se contaron los ovocitos vitelogénicos normales y los folículos atrésicos en toda la sección. Los individuos que mostraban atresia masiva no fueron considerados para la estimación de la fecundidad.

\section{Análisis de la fecundidad}

Se usó el método gravimétrico para determinar la fecundidad (Bagenal y Braum 1978) en los mismos individuos sometidos al análisis histológico. Todos los individuos se 


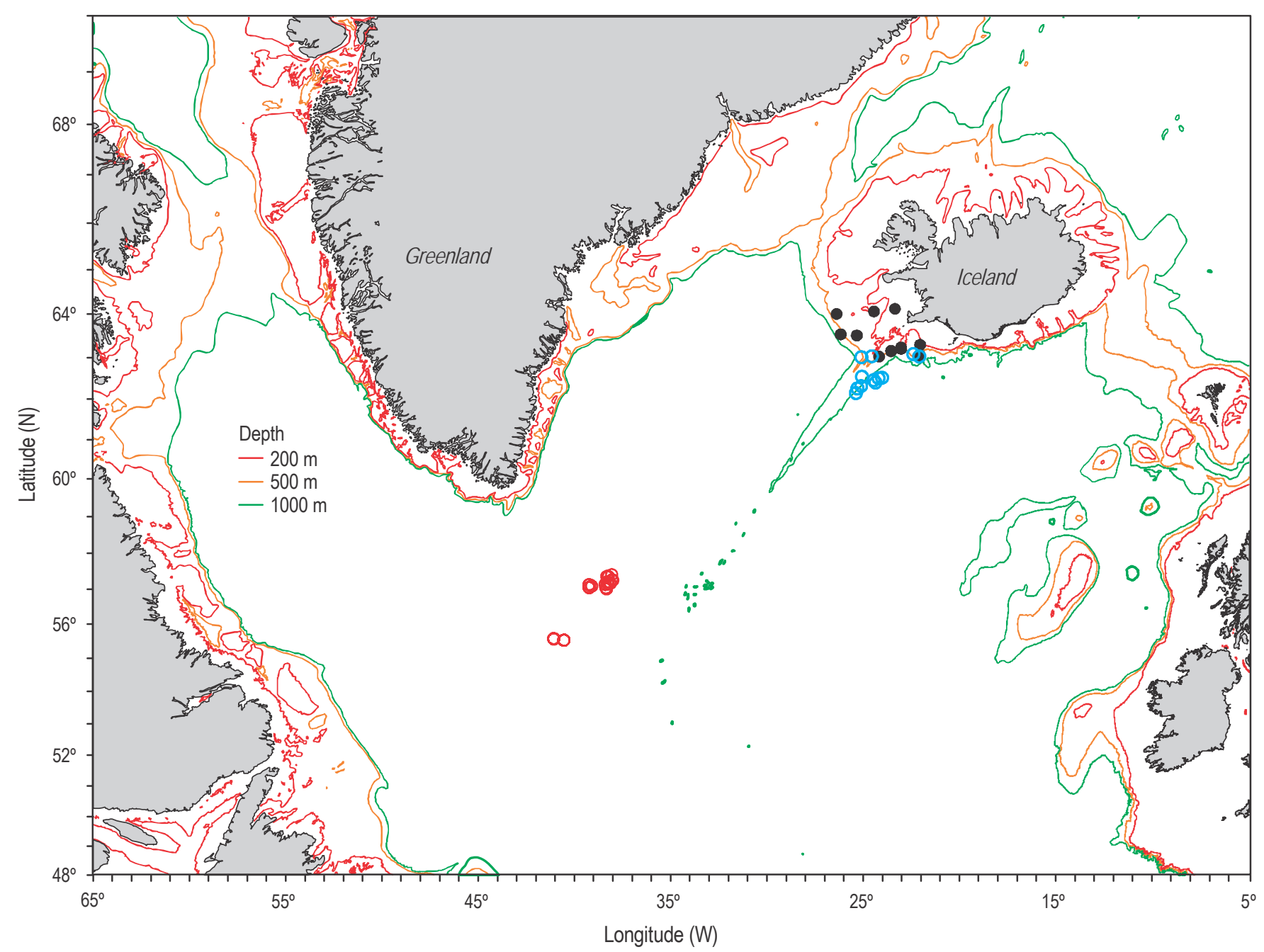

Figure 1. Sampling area of Sebastes norvegicus (filled circles) and Sebastes mentella (Iceland, blue circles; Irminger Sea, red circles) for fecundity analysis. Depth contours are $200 \mathrm{~m}$ (red), $500 \mathrm{~m}$ (orange), and $1000 \mathrm{~m}$ (green).

Figura 1. Área de muestreo de Sebastes norvegicus (círculos rellenos) y Sebastes mentella (Islandia, círculos azules; mar de Irminger, círculos rojos) para análisis de fecundidad. Los contornos de profundidad son $200 \mathrm{~m}$ (rojo), $500 \mathrm{~m}$ (naranja) y $1000 \mathrm{~m}$ (verde).

counted, oocytes were placed in a glycerine/water solution (1:3) in order to keep their form and to prevent them from splitting (Fitzhugh et al. 1993, McBride and Thurman 2003).

Oocyte counts and size measurements were obtained at the same time using a computer-aided image analysis system. Measurements were performed using the software QWin (Leica Imaging Systems) on a computer connected to a video camera (Leica DFC490, 8 megapixels) mounted on an automated macroscope (Leica Z6 APOA). The system provides automatic calibrated images at any magnification. Camera and light settings were established at the beginning of the analysis and kept constant throughout the whole analysis. Due to the amount of oocytes measured per sample (ca. 450 oocytes), and to allow a quick and precise image analysis, each sample was divided into $4-8$ subsamples, each of them analyzed separately. The subsample is placed on a watch glass under the macroscope objective. The shape of the watch glass groups all oocytes together in a single layer. The encontraban en la fase de desarrollo, mostrando ovocitos vitelogénicos pero ningún signo de ovulación (presencia de folículos postovulatorios y/o larvas). El peso del ovario después de su fijación se registró en el laboratorio a una precisión de $0.01 \mathrm{~g}$ y se tomaron submuestras de $\sim 250 \mathrm{mg}$ de la sección central del ovario. Los ovocitos se separaron del tejido conectivo mediante un proceso de lavado (modificado de Lowerre-Barbieri y Barbieri 1993) y se separaron por clases de talla mediante tamizado. El diámetro de los folículos en estado de alveolos corticales medido en las secciones histológicas definió el tamaño mínimo de malla de los tamices. Previo al conteo, los ovocitos se colocaron en una solución de glicerina/agua (1:3) para que mantuvieran su forma y evitar que se partieran (Fitzhugh et al. 1993, McBride y Thurman 2003).

Los ovocitos se contaron y midieron mediante un sistema de análisis de imágenes asistido por computadora. Las mediciones se realizaron con el programa QWin (Leica Imaging 
Table 1. Number of analyzed gonads, mean body size, and standard deviation (SD) by species, stock, year, and month.

Tabla 1. Número de gónadas analizadas, talla corporal media y desviación estándar (SD) por especie, población, año y mes.

\begin{tabular}{|c|c|c|c|c|c|c|}
\hline Species & Area/stock & Year & Month & $n$ & Mean size & SD \\
\hline Sebastes norvegicus & & 2001 & 10 & 8 & 42.4 & 5.4 \\
\hline \multirow[t]{5}{*}{ Sebastes mentella } & Iceland & 2001 & 10 & 17 & 44.6 & 2.9 \\
\hline & & 2001 & 11 & 14 & 45.0 & 3.2 \\
\hline & Irminger Sea & 2001 & 9 & 26 & 37.0 & 3.3 \\
\hline & & 2001 & 10 & 13 & 37.2 & 2.0 \\
\hline & & 2002 & 10 & 29 & 38.0 & 2.9 \\
\hline
\end{tabular}

image analysis described below identifies each oocyte even if they are touching each other. Oocytes were counted and measured using a semiautomatic software routine developed by one of the authors (FS-R) for this study. The routine lets the user upload or acquire a digital image (fig. 2a) that is then automatically transformed by applying successive morphological operators (erosion and dilation), until converting the image data into a binary image that accurately represents the oocytes that have to be measured and counted (fig. 2b). The oocytes in the binary image are then separated using segmentation algorithms (fig. 2c). During the automatic process the user can manually intervene in the key steps and modify the algorithm parameters. Then, the routine undergoes several measurements of each binary object, i.e., oocyte (fig. 2d). Oocytes with a diameter (longest or shortest) out of the range defined by the mean $\pm 2.5 \times$ standard deviation were considered outliers and completely excluded from the analyses. Oocytes with a roundness value higher than 1.15 were considered as departing from the sphericity and excluded from the diameter estimation, but included for the fecundity estimation. The final oocyte diameter was defined as the ratio between the longest and shortest diameter.

Potential fecundity for each individual was estimated as the ratio of the ovary weight after fixation and the subsample weight multiplied by the total number of oocytes in the subsample.

Relative fecundity of each female was estimated as the ratio between potential fecundity and female gutted weight. Relationships between fecundity and length, gutted weight, gonadosomatic index (GSI), and condition factor (K) were studied in order to explore which of them explained better the fecundity variability. $\mathrm{K}$ was estimated as the ratio between gutted weight and the cube of the respective length. For most fish, fecundity increases geometrically with length and weight, and is best described by a power function. However, we have explored the data with a linear fit and a power fit using a generalized linear model (GLM) and the Akaike Information Criterion (AIC) to select the best model. A Gaussian GLM with log link was finally used to investigate
Systems) en una computadora conectada a una cámara de video (Leica DFC490, 8 megapixeles) en un macroscopio automatizado (Leica Z6 APOA). El sistema proporciona imágenes calibradas de manera automática a cualquier magnificación. La configuración de la cámara y de la iluminación se establecieron al principio del análisis y se mantuvo constante a lo largo de éste. Debido al número de ovocitos medidos por muestra (ca. 450 ovocitos), y para permitir un análisis rápido y preciso de las imágenes, cada muestra se dividió en 4-8 submuestras, cada una analizada individualmente. La submuestra se coloca en un vidrio de reloj debajo del objetivo del macroscopio, y la forma del vidrio de reloj agrupa todos los ovocitos en una sola capa. El análisis de las imágenes (descrito a continuación) identifica cada ovocito aun cuando se están tocando. Los ovocitos se contaron y midieron mediante una rutina computacional semiautomática desarrollada por uno de los autores (FS-R) para este estudio. La rutina le permite al usuario cargar o adquirir una imagen digital (fig. 2a) que es transformada automáticamente al aplicar operadores morfológicos sucesivos (erosión y dilatación), hasta convertir los datos de la imagen en una imagen binaria que representa con precisión los ovocitos que se van a medir y contar (fig. 2b). Los ovocitos en la imagen binaria se separan mediante algoritmos de segmentación (fig. 2c). Durante el proceso automático, el usuario puede intervenir manualmente en los principales pasos y modificar los parámetros del algoritmo. La rutina subsecuentemente realiza varias mediciones de cada objeto binario, en este caso el ovocito (fig. 2d). Los ovocitos con un diámetro (mayor o menor) fuera del intervalo definido por la media $\pm 2.5 \times$ desviación estándar fueron considerados atípicos y se excluyeron del análisis. Al considerar que los ovocitos con un valor de redondez mayor que 1.15 se apartaban de la esfericidad, se excluyeron de la estimación del diámetro pero se incluyeron en la estimación de la fecundidad. El diámetro ovocitario final se definió como la razón entre el diámetro más largo y el más corto.

La fecundidad potencial de cada individuo se estimó como la razón del peso del ovario después de su fijación y el 

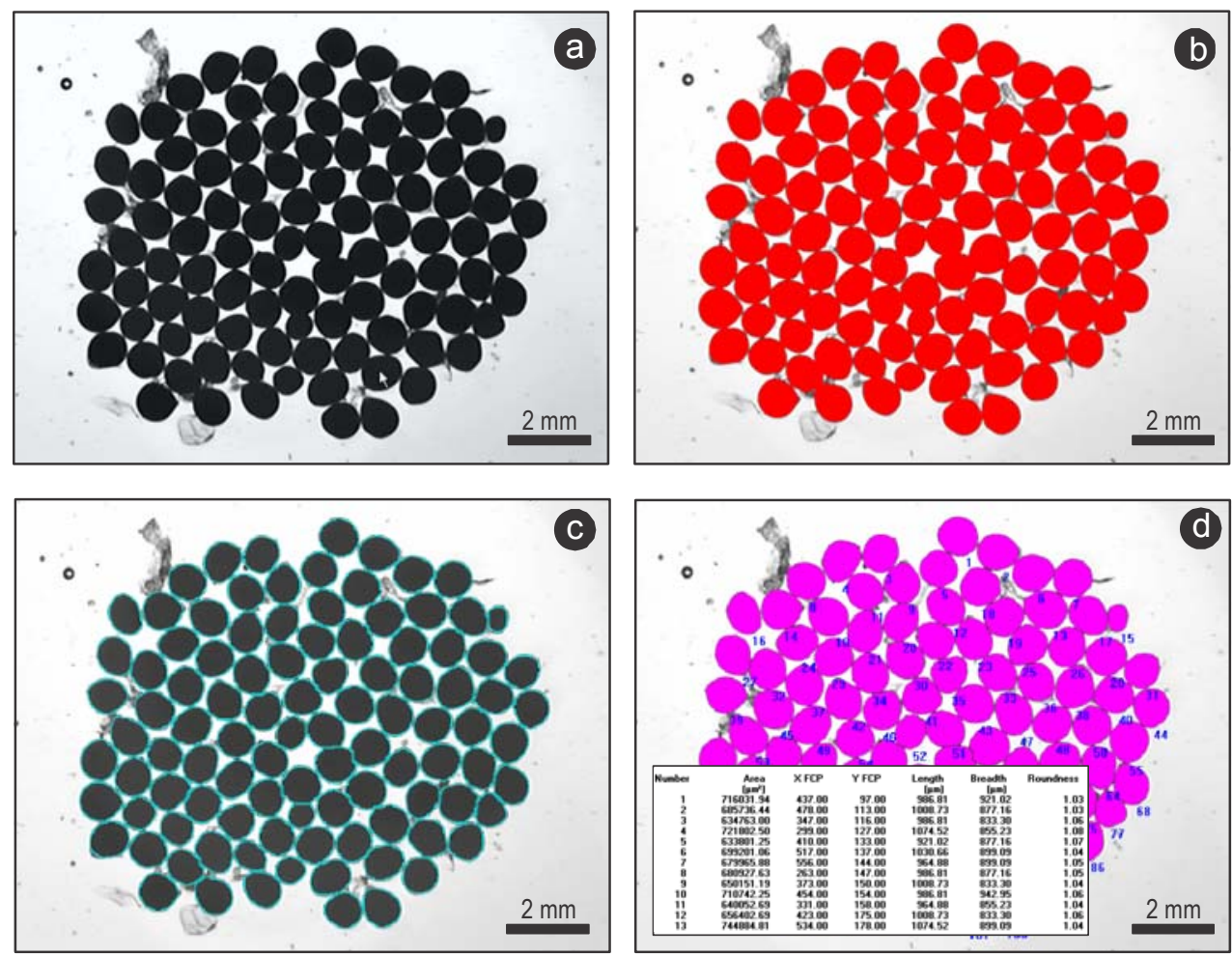

Figure 2. Images showing the different steps of the semiautomatic routine for counting and measuring oocytes. (a) Original digital image of oocytes before analysis. (b) The same image with a binary overlay (red layer) showing selection of the area to be measured and counted. (c) Binary image after applying segmentation algorithms and showing individual oocytes (outlined in blue). (d) Performance of automatic measurements of binary objects (i.e., oocytes; pink layer).

Figura 2. Imágenes mostrando los diferentes pasos de la rutina semiautomática para contar y medir ovocitos. (a) Imagen digital original de los ovocitos antes del análisis. (b) La misma imagen con una capa binaria sobrepuesta (capa roja) que muestra el área seleccionada para realizar las mediciones y los conteos. (c) Imagen binaria después de aplicar los algoritmos de segmentación y que muestra a los ovocitos individuales (contornos azules). (d) Ejecución de las mediciones automáticas de los objetos binarios (i.e., los ovocitos; capa rosa).

maternal effects, for each female attribute separately and with all predictors in the same model. To estimate fecundity downregulation, analyses were conducted for each month separately. Differences in mean oocyte diameter between months were compared using ANOVA and the Tukey HSD post-hoc test. GLMs with each of the female features as covariates were used to compare fecundity relationships by species, stock, and month. For this purpose the linear regressions of fecundity and length were made using log-transformation of variables. R (R Development Core Team 2011) was used for all calculations.

\section{RESULTS}

Five out of 148 ovaries showed massive atresia (i.e., with more than $20 \%$ of developing oocytes being atretic). All of them belonged to S. mentella collected in November 2002 in mid-vitellogenesis (stage 5, mean diameter of normal oocytes was $833 \mu \mathrm{m}$ ). The mean diameter of normal vitellogenic oocytes did not differ between these females and the others from the same month $(F=1.63, P=0.22)$; however, relative fecundity was significantly lower in those females peso de la submuestra multiplicado por el número total de ovocitos en la submuestra.

La fecundidad relativa de cada hembra se estimó como la razón entre la fecundidad potencial y el peso eviscerado. Se estudiaron las relaciones entre la fecundidad y la longitud corporal, el peso eviscerado, el índice gonadosomático (IGS) y el factor de condición (K) para analizar cuál explicaba mejor la variabilidad de la fecundidad. Se estimó K como la razón entre el peso eviscerado y el cubo de la longitud respectiva. En la mayoría de los peces, la fecundidad aumenta geométricamente con la longitud y el peso, y es mejor descrita por una función potencial. Nosotros analizamos los datos con un ajuste lineal y un ajuste potencial mediante un modelo lineal generalizado (MLG) y el criterio de información de Akaike (CIA) para seleccionar el mejor modelo. Se decidió usar un MLG gaussiano con enlace logarítmico para investigar los efectos maternales, para cada atributo femenino por separado y con todos los predictores en el mismo modelo. Para estimar la regulación decreciente de la fecundidad, los análisis se realizaron para cada mes por separado. Se compararon las diferencias en el diámetro ovocitario promedio entre meses mediante un análisis de varianza 
$(F=25.49, P<0.001)$. Since these samples would probably affect the subsequent fecundity analyses, they were not further considered in this study.

Non-vitellogenic oocytes appear as very small and fully transparent oocytes in the connective tissue, and they were not counted or measured by the software routine. Of the rest of the oocytes, only 159 oocytes out of 84,124 (0.19\%) were considered outliers, most of them being very small. These outliers were considered non-developing oocytes (i.e., vitellogenic oocytes that interrupted their development at an early stage) and so they were not considered for the fecundity estimation. On the other hand, up to $12.3 \%$ of the oocytes showed a roundness factor higher than 1.15 and were excluded from the diameter estimation.

\section{Oocyte development}

All S. norvegicus females were found in a similar developmental stage, most of them at vit3. They were captured (sampled) in October but in three different years (table 1). On the contrary, S. mentella females were at different developmental stages. They were captured from September to November in two different years. However, differences in developmental stage were not related to sampling time, except for S. mentella in the Irminger Sea (fig. 3a) that showed a significant increase in oocyte diameter between September and October (ANOVA, $F=62.12, P<0.001$ ). The mean oocyte diameter (individuals at different developmental stage pooled) was significantly different between species (ANOVA, $F=292.98, P<0.001$ ) and between stocks (ANOVA, $F=171.91, P<0.001$ ). Histological developmental stage and oocyte diameter were highly correlated (Spearman $\mathrm{R}=0.80, P<0.001$, all species and stocks pooled), with low dispersion around the mean for each stage (fig. $3 \mathrm{~b}$; i.e., oocyte diameter is a proper index of oocyte development). However, the mean oocyte diameter was significantly different between Irminger Sea and Icelandic S. mentella at all stages except stage 5 (all months pooled, ANOVA, $P<0.05$; fig. $3 \mathrm{c}$ ).

Oocyte diameter was not related to female body length or gutted weight in S. norvegicus and in the Irminger Sea S. mentella (GLM, $P>0.5$ in all cases), but was positively and significantly related in Icelandic S. mentella (GLM, $P<0.001$ ), although explaining little variance (less than $30 \%$ ). The condition factor was not related to oocyte diameter in any case. However, there was a significant difference in female length between the $S$. mentella stocks (ANOVA, $F=54.48, P<0.001)$.

\section{Fecundity regulation in S. mentella}

Potential fecundity in S. mentella (fig. 4a) increased significantly with female length in each month (GLM, $P<0.001$ for all months) but decreased significantly at all sizes from September to November (GLM, $P<0.001$ for all
(ANOVA) y la prueba HSD de Tukey. Se usaron MLGs con cada una de las características maternales como covariantes para comparar las relaciones de fecundidad por especie, población y mes. Para este propósito, se realizaron regresiones lineales de la fecundidad y longitud corporal mediante la transformación logarítmica de las variables. Se usó R ( R Development Core Team 2011) para todos los cálculos.

\section{RESUltados}

Cinco de los 148 ovarios mostraron atresia masiva (i.e., más del $20 \%$ de los ovocitos eran atrésicos). Todos pertenecieron a hembras de $S$. mentella recolectadas en noviembre de 2002 en estado vit5 (vitelogénesis media, diámetro promedio de ovocitos normales $=833 \mu \mathrm{m}$ ). El diámetro promedio de ovocitos vitelogénicos normales de estas hembras no difirió del de las otras hembras del mismo mes $(F=1.63$, $P=0.22$ ), pero su fecundidad relativa fue significativamente menor $(F=25.49, P<0.001)$. En vista de que estas muestras probablemente afectarían los análisis de fecundidad subsecuentes, ya no se consideraron más en este trabajo.

Los ovocitos no vitelogénicos aparecen como ovocitos muy pequeños y totalmente transparentes en el tejido conectivo, y no fueron contados o medidos por la rutina computacional. De los demás ovocitos, sólo 159 ovocitos de los 84,124 (0.19\%) fueron considerados atípicos, la mayoría siendo muy pequeños; éstos se consideraron ovocitos no desarrollados (i.e., ovocitos vitelogénicos que interrumpieron su desarrollo en un estado temprano) y no se usaron para estimar la fecundidad. Así mismo, hasta $12.3 \%$ de los ovocitos mostraron un factor de redondez mayor que $1.15 \mathrm{y}$ se excluyeron de la estimación del diámetro.

\section{Desarrollo ovocitario}

Todas las hembras de $S$. norvegicus se encontraban en un estado de desarrollo similar, la mayoría en vit3. Fueron capturadas (muestreadas) en octubre pero en tres años diferentes (tabla 1). Al contrario, las hembras de S. mentella mostraron diferentes estados de desarrollo. Fueron capturadas entre septiembre y noviembre en dos años distintos; sin embargo, las diferencias en el estado de desarrollo no se relacionaron con la fecha de muestreo, excepto en el caso de S. mentella del mar de Irminger (fig. 3a) que mostró un aumento significativo en el diámetro de los ovocitos entre septiembre y octubre (ANOVA, $F=62.12, P<0.001$ ). El diámetro promedio de los ovocitos (todos los individuos en diferentes estados de desarrollo combinados) fue significativamente diferente entre especies (ANOVA, $F=292.98, P<0.001$ ) y entre poblaciones (ANOVA, $F=171.91, P<0.001$ ). Se observó una alta correlación entre estado de desarrollo histológico y el diámetro ovocitario $(\mathrm{R}$ de Spearman $=0.80, P<0.001$, todas las especies y poblaciones combinadas), con baja dispersión alrededor de la media para cada estado (fig. 3b; i.e., el diámetro de los ovocitos es un índice adecuado para el 


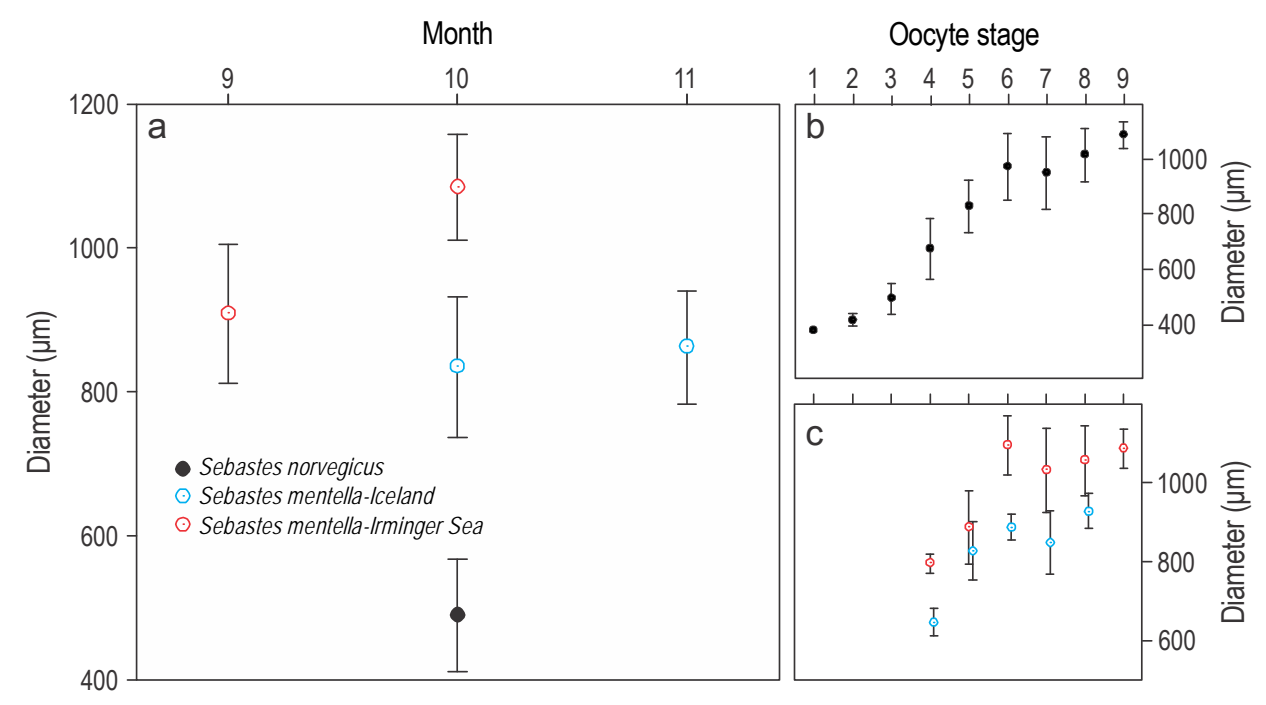

Figure 3. Mean oocyte diameter in the Irminger Sea and Icelandic waters (a) by month, (b) by oocyte developmental stage (all species and stocks combined), and (c) for Sebastes mentella stocks. Whiskers represent standard deviation.

Figura 3. Diámetro ovocitario promedio en el mar de Irminger y aguas islándicas (a) por mes, (b) por estado de desarrollo ovocitario (especies y poblaciones combinadas) y (c) para las poblaciones de Sebastes mentella. Las pestañas representan la desviación estándar.

comparisons). Relative fecundity (fig. 4b) decreased significantly from September to November, from 98 oocytes $\mathrm{g}^{-1}$ female in September to 64 and 52 oocytes $\mathrm{g}^{-1}$ female in October and November, respectively (ANOVA, $F=31.14$, $P<0.001)$. This trend clearly shows a down-regulation of the fecundity. Mean relative fecundity (fig. 4c) declined in relation to oocyte diameter when using a power function (GLM on log-transformed variables, $r^{2}=0.67, P<0.001$ ).

Fecundity decreased by $34-36 \%$ between September and October virtually at the same rate at all size classes $(30-50 \mathrm{~cm}$, fig. 4d). However, from October to November, fecundity down-regulation rates were clearly influenced by female length, ranging from $19 \%$ in larger females to $36 \%$ in the smallest (fig. 4d). Thus, from September to November fecundity decreased by $51 \%$ on average, ranging from $46 \%$ to $59 \%$.

Due to the effect of down-regulation, potential fecundity was hardly comparable between the S. mentella stocks because the September samples were taken from the Irminger Sea and the November samples from the Icelandic slope. The October samples were taken from both stocks (table 1), but there was virtually no overlap in female body size between stocks. Yet, the fecundity-length relationships within each stock did not differ from the common fecundity-length relationship (fig. 4a, GLM, $P=0.086$ ). However, when considering the same oocyte developmental stage $(700-1000 \mu \mathrm{m}$ diameter range, stages 7 and 8), potential fecundity differed significantly between stocks (GLM, $P<0.0001$ ). It is not possible to elucidate whether fecundity between stocks really differs or whether it is oocyte diameter that is different due to the down-regulation feature. desarrollo ovocitario). No obstante, el diámetro promedio fue significativamente diferente entre S. mentella del mar de Irminger y de aguas islándicas en todos los estados excepto el 5 (todos los meses combinados, ANOVA, $P<0.05$; fig. 3c).

No se observó una relación entre el diámetro ovocitario y la longitud corporal o el peso eviscerado de $S$. norvegicus y de $S$. mentella del mar de Irminger (MLG, $P>0.5$ en todos los casos), pero sí se observó una relación positiva y significativa para S. mentella de aguas islándicas (MLG, $P<0.001$ ), aunque explica poca varianza $(<30 \%)$. El factor de condición no se relacionó con el diámetro ovocitario en ningún caso; sin embargo, se observó una diferencia significativa en la longitud de las hembras de las poblaciones de S. mentella (ANOVA, $F=54.48, P<0.001$ ).

\section{Regulación de la fecundidad en S. mentella}

La fecundidad potencial de S. mentella (fig. 4a) aumentó significativamente con la longitud corporal en cada mes (MLG, $P<0.001$ para todos los meses), pero disminuyó significativamente en todas las tallas de septiembre a noviembre (MLG, $P<0.001$ para todas las comparaciones). La fecundidad relativa (fig. 4b) disminuyó significativamente entre septiembre y noviembre, de 98 ovocitos $\mathrm{g}^{-1}$ hembra en septiembre a 64 y 52 ovocitos $\mathrm{g}^{-1}$ hembra en octubre y noviembre, respectivamente (ANOVA, $F=31.14$, $P<0.001)$. Esta tendencia claramente muestra una regulación decreciente de la fecundidad. La fecundidad relativa promedio (fig. 4c) disminuyó en relación con el diámetro ovocitario después de aplicar una función potencial (MLG de 

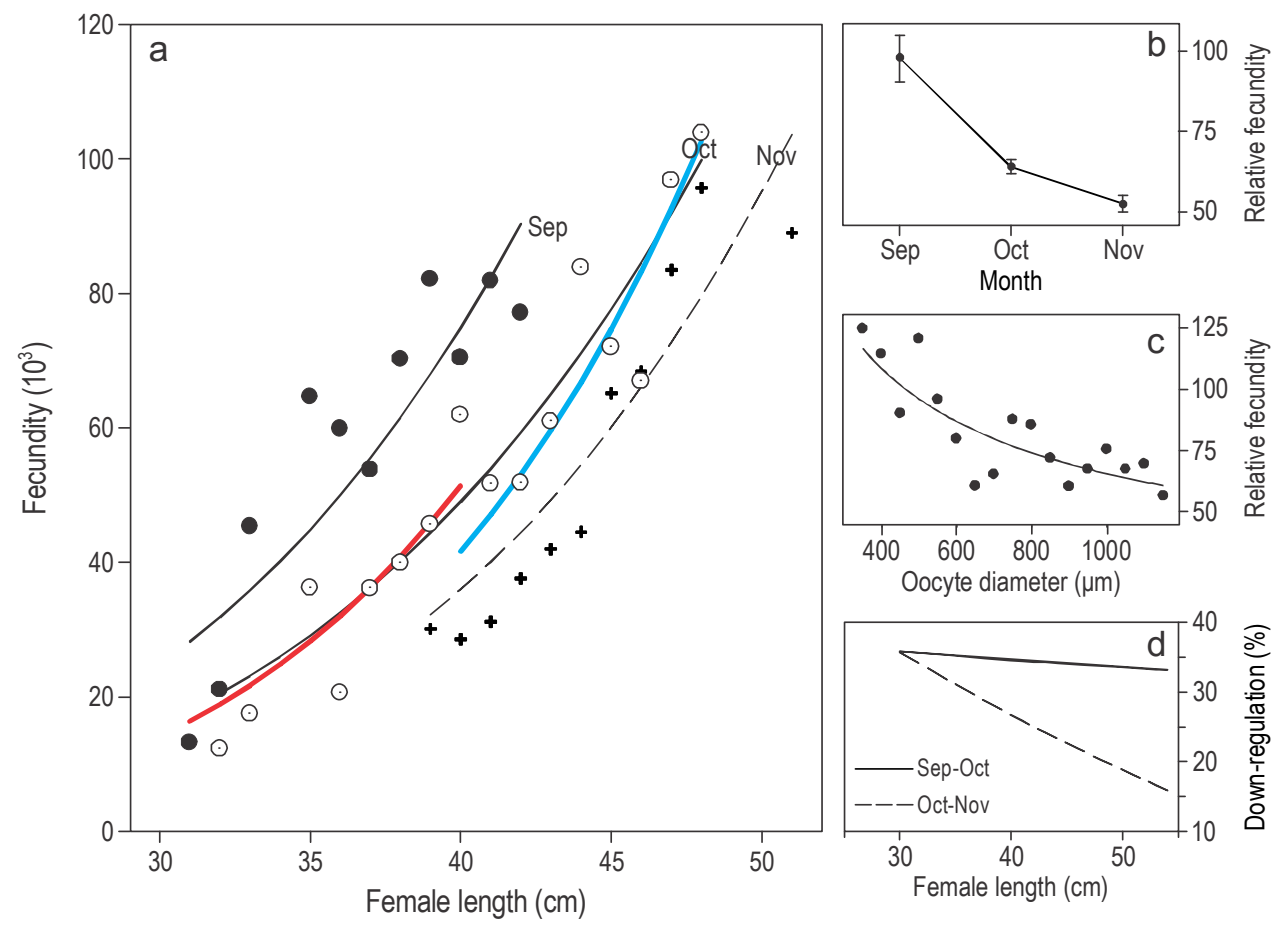

Figure 4. Fecundity analysis of Sebastes mentella in the Irminger Sea and Icelandic waters. (a) Fecundity-female length relationships by month; for October, the relationships for the Irminger Sea (red line) and Iceland (blue line) stocks are shown. For graph clarity only the mean fecundity by size class is shown. (b) Relative fecundity (mean and standard error). (c) Mean relative fecundity (mean and standard error) by oocyte diameter class. (d) Proportion of oocytes down-regulated by female length between September and November.

Figura 4. Análisis de la fecundidad de Sebastes mentella en el mar de Irminger y aguas islándicas. (a) Relaciones entre la fecundidad y longitud de hembras por mes; para octubre, se muestran las relaciones para las poblaciones del mar de Irminger (línea roja) e Islandia (línea azul). Para claridad, sólo se muestra la fecundidad promedio por clase de talla. (b) Fecundidad relativa (media y error estándar). (c) Fecundidad relativa media (media y error estándar) por clase de diámetro ovocitario. (d) Proporción de ovocitos con regulación decreciente $v s$ longitud corporal de las hembras entre septiembre y noviembre.

\section{Maternal effects on fecundity}

October was the month with the largest number of samples available for both species (table 1), so it was chosen to analyze potential fecundity variation in relation to maternal features. Given the significant difference in oocyte diameter between species, a comparative analysis between species was not made.

Potential fecundity in S. norvegicus ranged from 34,500 to 212,000 oocytes for females measuring between 33 and $52 \mathrm{~cm}$ (450 to $1800 \mathrm{~g}$ ). The estimated mean potential fecundity was 123,300 oocytes. Relative fecundity ranged from 72 to 180 oocytes $\mathrm{g}^{-1}$ of gutted weight (average of 116 oocytes $\mathrm{g}^{-1}$ ). Potential fecundity fitted better to a power than to a linear function for all predictors used (based on AIC from GLM comparison, fig. 5). All maternal features had a significant influence on fecundity except $\mathrm{K}$ (table 2). However, the variance explained by GSI was too low $(20 \%)$ and only acceptable for length and weight (above 70\%). The allometric coefficient of the fecundity-length relationship differed significantly from 3 (table 2), yet the complete model showed that only female length had a significant las variables transformadas logarítmicamente, $r^{2}=0.67$, $P<0.001)$.

La fecundidad disminuyó 34-36\% entre septiembre y octubre, casi a la misma tasa en todas las clases de talla (30-50 cm, fig. 4d). De octubre a noviembre, las tasas de regulación decreciente estuvieron claramente influenciadas por la longitud corporal, variando de $19 \%$ en hembras de mayor tamaño a $36 \%$ en las más pequeñas (fig. $4 \mathrm{~d}$ ). Por lo tanto, de septiembre a noviembre la fecundidad decreció $51 \%$ en promedio, variando de $46 \%$ a $59 \%$.

Debido al efecto de la regulación decreciente, no fue posible comparar bien la fecundidad potencial entre las poblaciones de $S$. mentella ya que las muestras de septiembre provienen del mar de Irminger y las de noviembre del talud de Islandia. Las muestras de octubre se obtuvieron de ambas poblaciones (tabla 1), pero casi no hay solapamiento en cuanto a la longitud corporal entre poblaciones. No obstante, la relación entre fecundidad y longitud en cada población no difirió de la relación común entre fecundidad y longitud (fig. 4a, MLG, $P=0.086$ ). Sin embargo, cuando se considera el mismo estado de desarrollo ovocitario (de 700 a $1000 \mu \mathrm{m}$ de diámetro, estados 7 y 8), la fecundidad potencial difirió 
influence on fecundity. Relative fecundity did not fit significantly to any maternal feature, neither using linear nor power functions (GLM, $P>0.05$ in all cases).

Potential fecundity in S. mentella ranged from 9,000 to 115,500 oocytes for females measuring between 32 and $48 \mathrm{~cm}$ (300 to $1500 \mathrm{~g})$. The estimated mean potential fecundity was 50,013 oocytes. Relative fecundity ranged from 18 to 94 oocytes $\mathrm{g}^{-1}$ of gutted weight (average of 64 oocytes $\mathrm{g}^{-1}$ ). Relative fecundity did not fit significantly to any maternal feature, neither using linear nor power functions (GLM, $P>$ 0.05 in all cases). However, potential fecundity significantly increased with all maternal features (table 2, fig. 5) except for GSI. As with S. norvegicus, length and weight were the best predictors of fecundity, with a coefficient of determination above 0.7 , while the predictive power of GSI and $\mathrm{K}$ was too low. The exponent of the fecundity-length power function differed significantly from 3 (table 2 ). In the case of GSI, however, the relationship with fecundity differed between stocks (Irminger Sea and Icelandic waters, GLM, $P<0.001$ ) and, therefore, a separate analysis was made for both. This analysis revealed that fecundity was significantly related to GSI in both stocks (table 2), especially the Iceland stock, with a coefficient of determination of 0.7. The complete model indicates that both length and GSI have a significant influence on fecundity; the deviance explained by this model increased to $86 \%$ with respect to the the simple fecundity-length model (table 2).

\section{DiscuSSION}

Follicular atresia is a rapid degenerative process by which oocytes at different stages are lost from the ovary (Hunter and Macewicz 1985, Guraya 1986). In determinate fecundity species, atresia is rarely generalized and, when present, it occurs sparsely over the reproductive season, while fishes with indeterminate fecundity show a generalized prevalence of atresia and resorption of mature oocytes at the end of the spawning season (Murua and Saborido-Rey 2003). The presence of atresia has been related to several factors (Guraya 1986), like light, temperature, or stress, but normally to decreased nutritional condition (Bagenal 1969, Wootton 1973, Kjesbu et al. 1991, Kraus 2002) and removal of damaged or abnormally developing oocytes (Bromley et al. 2000). However, generalized or massive atresia is not well documented, although it has been reported in several species (see the review by Rideout and Tomkiewicz 2011). In redfish, mass atresia is a common feature at previtellogenic stage and rarer during vitellogenesis (FS-R, unpublished data). Its presence during vitellogenesis means that fish will not spawn, since there is not sufficient time to develop another clutch of oocytes.

Potential and relative fecundity were higher earlier in the season and with lower mean oocyte diameter (i.e., in earlier developmental stage). This indicates that there is an important reduction of potential fecundity as the reproductive significativamente entre poblaciones (MLG, $P<0.0001$ ). No es posible elucidar si la fecundidad difiere entre poblaciones o si es el diámetro de los ovocitos el que difiere debido a la regulación decreciente.

\section{Efectos maternales en la fecundidad}

Octubre fue el mes con el mayor número de muestras para ambas especies (tabla 1), por lo que se escogió para analizar la variación de la fecundidad potencial en relación con las características maternales. Dada la considerable diferencia del diámetro ovocitario entre especies, no se realizó un análisis comparativo entre especies.

La fecundidad potencial de $S$. norvegicus varió de 34,500 a 212,000 ovocitos para hembras de 33 a $52 \mathrm{~cm}(450$ a $1800 \mathrm{~g}$ ). La fecundidad potencial promedio se estimó en 123,300 ovocitos. La fecundidad relativa varió de 72 a 180 ovocitos $\mathrm{g}^{-1}$ de peso eviscerado (116 ovocitos $\mathrm{g}^{-1}$ en promedio). La fecundidad potencial se ajustó mejor a una función potencial que a una función lineal para todos los predictores usados (con base en el CIA de la comparación de los MLG, fig. 5). Todas las características maternales tuvieron un efecto significativo en la fecundidad, excepto K (tabla 2); sin embargo, la varianza explicada por el IGS fue muy baja $(20 \%)$ y solamente aceptable para longitud y peso (arriba del 70\%). El coeficiente alométrico de la relación fecundidad-longitud difirió significativamente de 3 (tabla 2). El modelo completo mostró que sólo la longitud afectó significativamente la fecundidad. La fecundidad relativa no se ajustó significativamente a ninguna característica maternal, ni con la función lineal ni con la potencial (MLG, $P>0.05$ en todos los casos).

La fecundidad potencial de S. mentella varió de 9,000 a 115,500 ovocitos en hembras de 32 a $48 \mathrm{~cm}$ (300 a $1500 \mathrm{~g}$ ). La fecundidad potencial promedio se estimó en 50,013 ovocitos. La fecundidad relativa varió de 18 a 94 ovocitos $\mathrm{g}^{-1} \mathrm{de}$ peso eviscerado ( 64 ovocitos $\mathrm{g}^{-1}$ en promedio). La fecundidad relativa no se ajustó significativamente a ninguna característica maternal, ni con la función lineal ni con la potencial (MLG, $P>0.05$ en todos los casos); sin embargo, la fecundidad potencial aumentó significativamente con todas las características maternales (tabla 2, fig. 5) excepto el IGS. Al igual que para $S$. norvegicus, la longitud corporal y el peso fueron los mejores predictores de la fecundidad, con un coeficiente de determinación mayor que 0.7 , mientras que el poder predictivo del IGS y $\mathrm{K}$ fue muy bajo. El exponente de la función potencial fecundidad-longitud difirió significativamente de 3 (tabla 2); sin embargo, en el caso del IGS, se observó que la relación con la fecundidad difirió entre poblaciones (mar de Irminger y aguas islándicas, MLG, $P<0.001$ ) $\mathrm{y}$, por lo tanto, se analizaron por separado. Este análisis mostró que la fecundidad se relacionó significativamente con el IGS de ambas poblaciones (tabla 2), especialmente con la población islándica, con un coeficiente de determinación de 0.7. El modelo completo indica que tanto la longitud como el 

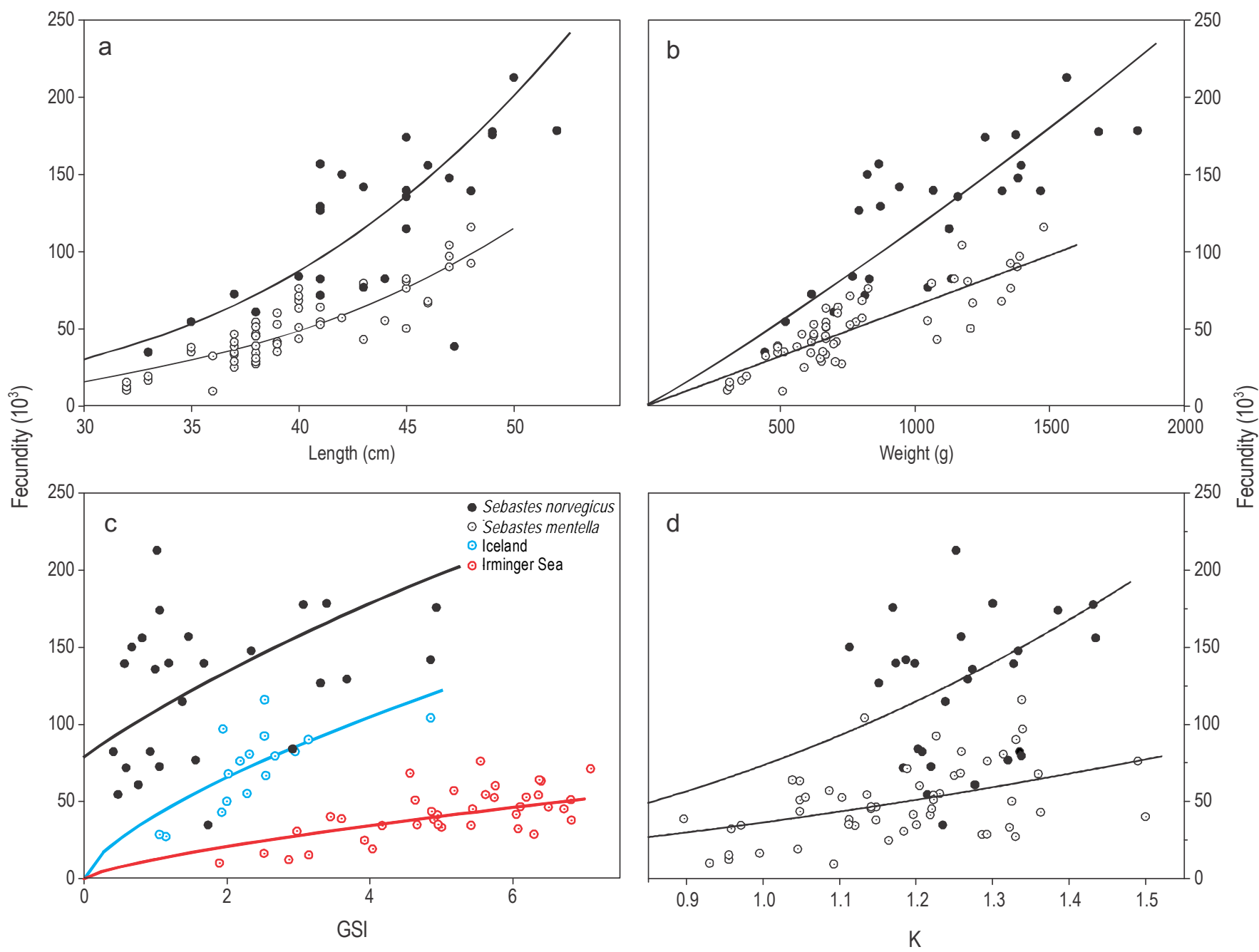

Figure 5. Fecundity of Sebastes norvegicus (filled circles) and Sebastes mentella (empty circles) in the Irminger Sea and Icelandic waters related to (a) total length, (b) gutted weight, (c) gonadosomatic index (GSI), and (d) condition factor. Samples of S. mentella in (c) are shown by location: Irminger Sea (red circles) and Icelandic waters (blue circles).

Figura 5. Fecundidad de Sebastes norvegicus (círculos rellenos) y Sebastes mentella (círculos vacíos)en el mar de Irminger y aguas islándicas en relación con (a) longitud total, (b) peso eviscerado, (c) índice gonadosomático (GSI) y (d) factor de condición. Las muestras de S. mentella en (c) se muestran por localidad: mar de Irminger (círculos rojos) y aguas islándicas (círculos azules).

season develops, and atretic losses must therefore be carefully quantified. Several studies have shown that not all the recruited oocytes (potential fecundity) develop into eggs (realized fecundity), and follicular atresia may account for a substantial part of the fecundity in a process referred to as down-regulation (Murua et al. 2003, Armstrong and Witthames 2012). Several species have been shown to recruit more follicles than are taken to full development, especially in capital spawners (such as redfish), where fecundity is then down-regulated by atresia in relation to available energy reserves (Kurita et al. 2003, Armstrong and Witthames 2012). The mechanism behind down-regulation seems to be related to the fact that it is energetically inexpensive to recruit a large quantity of small, early-stage vitellogenic follicles, but energetically expensive to grow them through the final stages of vitellogenesis (Kjesbu et al. 1991).
IGS tienen un efecto significativo en la fecundidad; la desviación explicada incrementó a $86 \%$ en relación con el modelo simple de fecundidad-longitud (tabla 2).

\section{DISCUSIÓN}

La atresia folicular es un proceso degenerativo y rápido mediante el cual los ovocitos en diferentes fases de desarrollo son eliminados (Hunter y Macewicz 1985, Guraya 1986). En especies con fecundidad determinada, la atresia raramente es generalizada y, cuando sucede, se presenta esporádicamente a lo largo de la temporada reproductiva, mientras que los peces con fecundidad indeterminada muestran una prevalencia generalizada de atresia y reabsorción de ovocitos maduros al final de la temporada de desove (Murua y Saborido-Rey 2003). Se ha relacionado la presencia de atresia con varios 
Table 2. Maternal effect on fecundity: results of the generalized linear model of maternal variables on fecundity estimated in October, for each predictor separately and for the complete model (fecundity length + weight + gonadosomatic index [GSI] + condition factor [K]).

Tabla 2. Efectos maternales en la fecundidad: resultados del modelo lineal generalizado de las variables maternales transformadas (logaritmo) sobre la fecundidad estimada en octubre, para cada predictor por separado y para el modelo completo (fecundidad $\sim$ longitud + peso + índice gonadosomático [GSI] + factor de condición [K]).

\begin{tabular}{|c|c|c|c|c|c|c|c|}
\hline & & $a$ & $b$ & \multicolumn{2}{|c|}{$95 \% \mathrm{CI}$} & $r^{2}$ & $P$ \\
\hline \multirow{10}{*}{$\begin{array}{l}\text { Sebastes norvegicus } \\
n=27\end{array}$} & Length & -2.070 & 3.644 & 3.127 & 4.160 & 0.766 & $<0.001$ \\
\hline & Weight & 4.125 & 1.088 & 0.826 & 1.350 & 0.726 & $<0.001$ \\
\hline & GSI & 11.645 & 0.551 & 0.123 & 0.978 & 0.203 & $<0.001$ \\
\hline & $\mathrm{K}$ & 11.249 & 1.864 & -0.910 & 4.637 & 0.065 & 0.1436 \\
\hline & & Estimate & Std. error & $t$ value & $P$ & & \\
\hline & Intercept & 5.650 & 2.986 & 1.892 & 0.072 & \multirow{5}{*}{\multicolumn{2}{|c|}{$\begin{array}{c}\text { Deviance } \\
\text { explained }=76 \%\end{array}$}} \\
\hline & Length & 0.140 & 0.061 & 2.277 & $<0.050$ & & \\
\hline & Weight & -0.001 & 0.001 & -0.975 & 0.340 & & \\
\hline & GSI & 0.164 & 0.118 & 1.390 & 0.178 & & \\
\hline & $\mathrm{K}$ & 0.537 & 1.122 & 0.479 & 0.637 & & \\
\hline \multirow{13}{*}{$\begin{array}{l}\text { Sebastes mentella } \\
n=55\end{array}$} & & $a$ & $b$ & \multicolumn{2}{|c|}{$95 \% \mathrm{CI}$} & $r^{2}$ & $P$ \\
\hline & Length & -6.255 & 4.609 & 3.870 & 5.348 & 0.738 & $<0.001$ \\
\hline & Weight & 2.792 & 1.200 & 0.993 & 1.408 & 0.709 & $<0.001$ \\
\hline & GSI & 10.656 & 0.021 & -0.294 & 0.336 & 0.336 & 0.8957 \\
\hline & GSI-Irminger & 8.925 & 0.991 & 0.550 & 1.431 & 0.345 & $<0.001$ \\
\hline & GSI-Iceland & 10.301 & 0.994 & 0.635 & 1.353 & 0.678 & $<0.001$ \\
\hline & $\mathrm{K}$ & 10.284 & 2.515 & 1.408 & 3.622 & 0.272 & $<0.001$ \\
\hline & & Estimate & Std. error & $t$ value & $P$ & & \\
\hline & Intercept & 5.141 & 1.558 & 3.301 & $<0.001$ & \multirow{5}{*}{\multicolumn{2}{|c|}{$\begin{array}{c}\text { Deviance } \\
\text { explained }=86 \%\end{array}$}} \\
\hline & Length & 0.109 & 0.039 & 2.817 & $<0.001$ & & \\
\hline & Weight & 0.000 & 0.001 & 0.151 & 0.8804 & & \\
\hline & GSI & 0.120 & 0.023 & 5.212 & $<0.001$ & & \\
\hline & $\mathrm{K}$ & 0.566 & 0.446 & 1.270 & 0.2098 & & \\
\hline
\end{tabular}

Our results show that the highest rate of down-regulation occurs at early development (small oocyte diameters), which differs from that observed in other species where down-regulation appears to occur mainly in the later stages of vitellogenesis (Armstrong and Witthames 2012 and references therein). However, female size seems to play an important role in down-regulation in redfish, but only during the late stages of development; that is, rates of down-regulation are similarly high at all sizes during early vitellogenesis, when on average fecundity is reduced by $35 \%$, but decline considerably in larger females later in the season. Although downregulation has been mostly associated with condition, the influence of size on atresia has been reported also for herring (Kennedy et al. 2011). Condition does not seem to have influenced oocyte diameter or relative fecundity; however, it positively increased with female size, so likely both, size and condition, were associated with the highest rate of downregulation at smaller sizes. factores (Guraya 1986), como la luz y temperatura o el estrés, pero en general con un estado nutricional disminuido (Bagenal 1969, Wootton 1973, Kjesbu et al. 1991, Kraus 2002) y la eliminación de ovocitos dañados o desarrollándose anormalmente (Bromley et al. 2000). No obstante, aunque se ha observado en varias especies, la atresia generalizada o masiva no ha sido bien documentada (ver revisión de Rideout y Tomkiewicz 2011). En la gallineta nórdica, la atresia masiva es común durante el estado previtelogénico pero infrecuente durante la vitelogénesis (FS-R, datos no publicados). Su presencia durante la vitelogénesis significa que los individuos no desovarán ya que no hay suficiente tiempo para desarrollar otro grupo de ovocitos.

La fecundidad potencial y relativa fueron mayores a principios de la temporada reproductiva cuando el diámetro ovocitario promedio fue menor (i.e., estado temprano de desarrollo). Esto indica que la fecundidad potencial disminuye considerablemente conforme avanza la temporada y las 
Knowledge of the down-regulation process is essential to select the proper sampling time and the oocyte developmental stage at which fecundity should be estimated (Kjesbu 2009). We have found that vitellogenesis occurs at different rates between species and stocks (i.e., in October the oocyte diameter was different between $S$. norvegicus and S. mentella, and also between the Icelandic and Irminger Sea stocks). Sampling for potential fecundity should be conducted as close as possible to the time of spawning (i.e., fertilization in redfish), to obtain unbiased estimations of potential fecundity. In redfish, oocyte diameter should be used as indicative of the proper moment to estimate fecundity. However, more studies are needed to assess how oocyte diameter in late vitellogenesis differs among redfish species and stocks. Alternatively, our approach allows the quantification of down-regulation using a regression of relative fecundity $v s$ follicle diameter, which provides standardized fecundity values for those follicle diameters close to the value at which oocytes will progress to fertilization, in redfish, or to spawning, in other species (Thorsen et al. 2006).

Histology of the Irminger Sea October samples showed that oocytes were already in advanced vitellogenesis, with an oocyte diameter above $1.1 \mathrm{~mm}$ on average. This value is coincident with that reported by Jones (1970) for the same quarter. Moreover, this size is close to the average size of prefertilized oocytes in Icelandic S. mentella (Jones 1970) and S. norvegicus collected when they were at a very late stage of oocyte maturation (migratory nucleus, or even fertilized eggs), showing an average diameter of $1.25 \mathrm{~mm}$ (FS-R, unpublished data). Studies of Pacific rockfish species have reported similar oocyte sizes at the very end of the developmental stage (Bowers 1992, Koya et al. 1995). It can therefore be hypothesized that in late October most, if not all, of the yolk has already been accumulated. Hence, the potential fecundity estimated in this study can be representative of realized fecundity, because from that stage on, few atretic losses are expected (Witthames et al. 2009).

Potential fecundity of $S$. mentella in the Irminger Sea ranged from 10,000 to 80,000 oocytes per female in the surveys conducted late in the year, when fecundity values are closer to those of realized fecundity. These values are generally in accordance with those previously obtained in the Irminger Sea (Jones 1969), but the fecundity-length relationship was quite different (fig. 6a). While fecundity at larger sizes was similar, it differs greatly at smaller ones. This difference is probably due to the way fecundity was estimated at earlier developing stages by Jones (1969), as shown by the high dispersion in the scatterplot (fig. 5 in Jones 1969). In fact, the values are similar to those obtained in this study in September. In the cited scatterplot, low fecundity values at larger sizes can be observed as outliers (likely due to the occurrence of atresia), modifying the curve shape and the parameter estimation. Fecundity of $S$. mentella has also been reported in the Barents Sea (Drevetnyak and Gusev 1996) and the Gulf of St. Lawrence (St. Pierre and de Lafontaine pérdidas atrésicas deben ser cuantificadas cuidadosamente. Varios trabajos han mostrado que no todos los ovocitos reclutados (fecundidad potencial) se convierten en huevos (fecundidad realizada), y la atresia folicular puede explicar una gran parte de la fecundidad en un proceso conocido como regulación decreciente (Murua et al. 2003, Armstrong y Witthames 2012). Se ha mostrado que varias especies reclutan más folículos de los que llevan a un desarrollo completo, especialmente en desovadores que dependen de reservas acumuladas (capital spawners), como la gallineta nórdica, en las cuales la fecundidad es regulada negativamente por atresia en relación con las reservas energéticas disponibles (Kurita et al. 2003, Armstrong y Witthames 2012). El mecanismo detrás de la regulación decreciente parece estar relacionado con el hecho de que es energéticamente poco costoso reclutar una gran cantidad de folículos vitelogénicos pequeños en estados tempranos de desarrollo, pero energéticamente costoso dejar que crezcan hasta el final de la vitelogénesis (Kjesbu et al. 1991).

Nuestros resultados muestran que la tasa de regulación decreciente es mayor durante el desarrollo temprano (diámetros ovocitarios pequeños), mientras que en otras especies la regulación decreciente se observa principalmente en los estados finales de la vitelogénesis (Armstrong y Witthames 2012 y referencias citadas). El tamaño de las hembras parece jugar un papel importante en la regulación decreciente de la gallineta nórdica, pero sólo durante las fases avanzadas de desarrollo; esto es, las tasas de regulación decreciente son igual de altas en todas las tallas durante la vitelogénesis temprana, cuando la fecundidad se reduce en un $35 \%$ en promedio, pero disminuyen considerablemente en hembras de mayor tamaño al final de la temporada. Aunque la regulación decreciente ha sido principalmente asociada con la condición, la influencia del tamaño en la atresia también ha sido documentada para Clupea harengus (Kennedy et al. 2011). La condición no parece haber influenciado el diámetro de los ovocitos o la fecundidad relativa; sin embargo, aumentó positivamente con el tamaño de las hembras, por lo que la mayor tasa de regulación decreciente en las hembras más pequeñas podría atribuirse tanto al tamaño como a la condición.

El conocimiento del proceso de regulación decreciente es importante para seleccionar el periodo de muestreo adecuado y el estado de desarrollo ovocitario cuando se debería estimar la fecundidad (Kjesbu 2009). Hemos observado que la vitelogénesis sucede a diferentes tasas entre especies y poblaciones (i.e., en octubre el diámetro ovocitario difirió entre S. norvegicus y S. mentella, así como entre la población del mar de Irminger y la islándica). Los estudios de la fecundidad potencial deberían realizarse lo más cercano posible al tiempo de desove (i.e., fertilización en la gallineta nórdica), para obtener estimaciones no sesgadas de la fecundidad potencial. En el caso de la gallineta nórdica, el diámetro de los ovocitos debería usarse como una indicación del momento adecuado para estimar la fecundidad; sin embargo, 
1995). Though sampling was conducted during the same month (January) in these two studies, fecundity values were considerably different, especially at larger sizes, but they were quite similar to our October and November values, respectively (fig. 6a). The effect of down-regulation is likely the cause of these differences. Thus, the low fecundity found in the Gulf of St. Lawrence may be explained by the potential fecundity decrease as the reproductive cycle progresses, because those fecundity values were almost identical to our November values. Unfortunately, no information on oocyte diameter is given in these two studies in order to compare the developmental stage. In relation to other North Atlantic Sebastes species, fecundity has been estimated only in S. norvegicus from Iceland and the Faroe Islands in late winter (Raitt and Hall 1967). Fecundity values of that study were very similar to those obtained for $S$. mentella from the Barents Sea and also to our October values, but were far below the $S$. norvegicus values in this study (fig. 6b). Again, this can be likely due to the occurrence of down-regulation, as in our study average oocyte diameter for S. norvegicus was still low; that is, vitellogenesis was in an earlier stage compared with the samples collected by Raitt and Hall (1967) in late winter, which were probably in advanced vitellogenesis. The examples discussed above show that comparing fecundity values estimated at different developmental stages is not reliable.

Pacific Sebastes species show a huge variation both in fecundity and in reproductive strategies, as can be seen in different studies (Gunderson et al. 1980, Boehlert et al. 1982, Love and Johnson 1998) and especially in the review of fecundity in several rockfish species carried out by Haldorson and Love (1991). Comparing individuals of the same size, nearly all the Pacific species showed higher fecundity values than those obtained in this study. The cause can be related to the temperature of the waters, as most of the studied Pacific species inhabited temperate northeastern Pacific waters south of $55^{\circ}$ latitude. Only Sebastes alutus, the species living in colder and northern waters, showed fecundity values close to those of $S$. mentella. The relative fecundity of 23 Sebastes species off California (MacGregor 1970) was two to eight times higher than in S. mentella in this study. However, oocyte diameter in those Pacific rockfish (an average of $0.6-0.8 \mathrm{~mm}$ ) is considerably lower than in S. mentella.

The exponent of the power relationship between fecundity and length of $S$. mentella was greater than 3 , which is in accordance with previous values estimated for S. mentella in other areas (St. Pierre and de Lafontaine 1995) and for other Sebastes species from the Pacific and Atlantic oceans (Corlett 1964, Raitt and Hall 1967, Gunderson 1977, Haldorson and Love 1991). It implies that total egg production increases notably with the proportion of larger fish in the spawning stock, rather than with the spawning stock biomass itself (i.e., there is an increasing reproductive potential with female size in redfish). The assumption that spawning stock biomass is proportional to the reproductive potential of the se requieren más estudios para evaluar cómo el diámetro ovocitario al final de la vitelogénesis difiere entre las especies y poblaciones. Alternativamente, nuestro enfoque permite la cuantificación de la regulación decreciente mediante una regresión de fecundidad relativa vs diámetro folicular, que proporciona valores de fecundidad estandarizados para los diámetros foliculares cercanos al valor al cual los ovocitos progresan a la fertilización, en la gallineta nórdica, o al desove, en otras especies (Thorsen et al. 2006).

El análisis histológico de las hembras capturadas en octubre en el mar de Irminger mostró que los ovocitos ya se encontraban en estado de vitelogénesis avanzada, con un diámetro ovocitario mayor que $1.1 \mathrm{~mm}$ en promedio. Este valor coincide con lo documentado por Jones (1970) para el mismo trimestre. Así mismo, esta talla es similar a la talla promedio de ovocitos prefertilizados en S. mentella (Jones 1970) y S. norvegicus capturadas en aguas islándicas cuando los ovocitos se encontraban en una fase avanzada de maduración (núcleo migratorio o huevos fertilizados), con un diámetro promedio de $1.25 \mathrm{~mm}$ (FS-R, datos no publicados). En otros estudios de especies de gallineta del Pacífico se registraron tallas ovocitarias similares al final del estado de desarrollo (Bowers 1992, Koya et al. 1995). Por lo tanto, es posible pensar que en octubre ya se ha acumulado la mayoría, si es que no todo, el vitelo. La fecundidad potencial estimada en el presente trabajo podría ser representativa de la fecundidad realizada, ya que a partir de ese estado, son pocas las pérdidas atrésicas (Witthames et al. 2009).

La fecundidad potencial de S. mentella del mar de Irminger varió de 10,000 a 80,000 ovocitos por hembra en los muestreos realizados a finales del año, cuando los valores de fecundidad se acercan a los valores de fecundidad realizada. En general, estos valores concuerdan con los valores obtenidos previamente para S. mentella del mar de Irminger (Jones 1969), pero la relación fecundidad-longitud fue diferente (fig. 6a). Aunque la fecundidad a tallas mayores fue similar, difirió considerablemente a tallas menores. Esta diferencia probablemente se debe al método empleado por Jones (1969) para estimar la fecundidad en los estados tempranos de desarrollo, como lo demuestra la alta dispersión en su gráfica (fig. 5 en Jones 1969). De hecho, los valores son similares a los obtenidos en el presente trabajo para septiembre. En la gráfica de dispersión mencionada, los valores bajos de fecundidad a mayores tamaños aparecen como atípicos (probablemente debido a la presencia de atresia), y modifican la forma de la curva y la estimación del parámetro. La fecundidad de S. mentella ha sido estudiada en el mar de Barents (Drevetnyak y Gusev 1996) y el golfo de San Lorenzo (St. Pierre y de Lafontaine 1995). A pesar de que en estos dos trabajos los muestreos se realizaron en el mismo mes (enero), los valores de fecundidad fueron considerablemente diferentes, especialmente a mayores tallas, pero fueron similares a nuestros valores de octubre y noviembre, respectivamente (fig. 6a). Estas diferencias probablemente se deben al efecto de la regulación decreciente. La baja fecundidad observada 


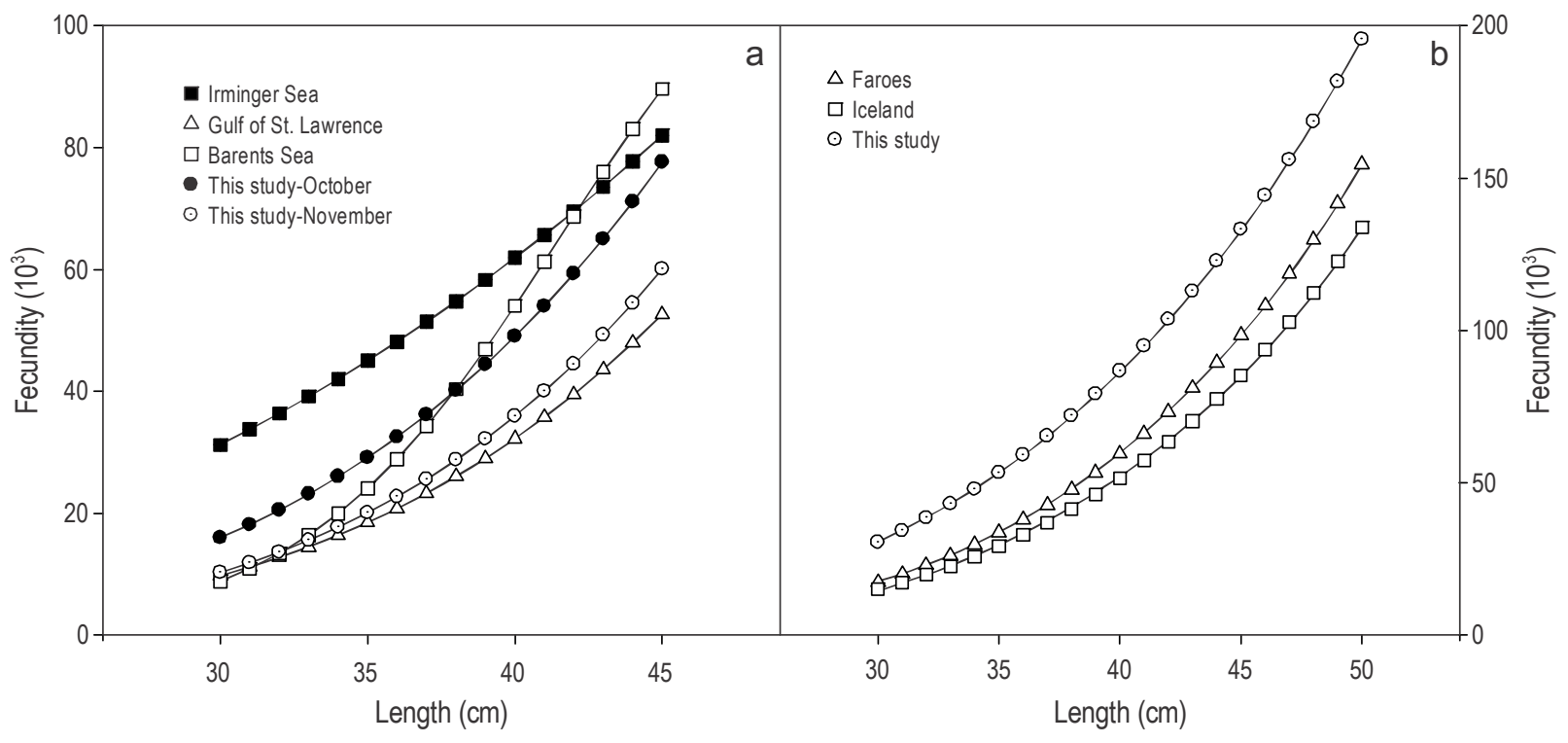

Figure 6. Comparison of fecundity-length relationships of (a) Sebastes mentella from the Irminger Sea (Jones 1969), Gulf of St. Lawrence (St. Pierre and de Lafontaine 1995), Barents Sea (Drevetnyak and Gusev 1996), and this study; and (b) S. norvegicus from the Faroe Islands and Iceland (Raitt and Hall 1967) and this study. Note the different scale between both graphs.

Figura 6. Comparación de las relaciones fecundidad-longitud de (a) Sebastes mentella del mar de Irminger (Jones 1969), el golfo de San Lorenzo (St. Pierre y de Lafontaine 1995), el mar de Barents (Drevetnyak y Gusev 1996) y el presente estudio; y (b) S. norvegicus de las islas Feroe e Islandia (Raitt y Hall 1967) y el presente estudio. Nótese la diferente escala entre ambas gráficas.

stock has long been recognized as invalid (Saborido-Rey and Trippel 2013). The influence of maternal attributes on reproductive features has been studied in different species through different factors, such as the influence of condition (feeding) on fecundity (Kjesbu et al. 1991, Bromley et al. 2000, Kraus et al. 2000) or the influence of age/size and condition on eggs and larval characteristics (Hislop 1988, Buckley et al. 1991, Marteinsdottir and Steinarsson 1998, Trippel 1998, Vallin and Nissling 2000, Saborido-Rey et al. 2003). In other species, female size and condition are positively correlated with egg diameter (Kjesbu et al. 1991, Marteinsdottir and Steinarsson 1998, Vallin and Nissling 2000, Marteinsdottir and Begg 2002). However, in this study, oocyte diameter was generally not influenced by any of the analyzed maternal features.

Summarizing, in redfish, weight and length have a significant influence on fecundity, but not on oocyte diameter. This may be a logical strategy in viviparous species, since the production of larger eggs does not confer any particular advantage to the larvae that develop within the ovary, but to invest energy surplus in producing more eggs is clearly an advantage. This may explain why fecundity was not influenced by condition at earlier stages of development, but was at later stages when oocytes significantly increased in size and fecundity was corrected by atretic losses. Varying energy storage in body weight may have reduced differentially the fecundity and hence the observed stronger correlation of condition, weight, and length. Given the importance of down-regulation in redfish, more research is necessary to en el golfo de San Lorenzo puede ser explicada por la disminución de la fecundidad potencial conforme progresa el ciclo reproductivo, ya que esos valores de fecundidad resultaron ser casi idénticos a nuestros valores para noviembre. Desafortunadamente, estos dos trabajos no proporcionan información sobre el diámetro de los ovocitos para poder comparar los estados de desarrollo. En relación con otras especies del género Sebastes en el Atlántico Norte, sólo se ha estimado la fecundidad en S. norvegicus de Islandia y las islas Feroe a finales del invierno (Raitt y Hall 1967). Los valores de fecundidad obtenidos en ese estudio fueron similares a los obtenidos para S. mentella del mar de Barents y a nuestros valores de octubre, pero fueron mucho menores que nuestros valores para $S$. norvegicus (fig. 6b). Esto también puede deberse a la presencia de regulación decreciente, ya que en nuestro estudio el diámetro ovocitario promedio para S. norvegicus fue bajo, lo que sugiere que las hembras se encontraban en estado más temprano de la vitelogénesis que los individuos capturados por Raitt y Hall (1967) a finales del invierno, que probablemente estaban en vitelogénesis avanzada. Estos ejemplos muestran que no es confiable comparar los valores de fecundidad estimados a diferentes estados de desarrollo.

Las especies de Sebastes del Pacífico muestran una gran variación en cuanto a la fecundidad y estrategias reproductivas, como se puede ver en diferentes estudios (Gunderson et al. 1980, Boehlert et al. 1982, Love y Johnson 1998) y especialmente en la revisión de varias especies de gallineta realizada por Haldorson y Love (1991). Al comparar los 
ascertain the atresia mechanisms in redfish and the relation to female attributes and the impact on population fecundity.

\section{ACKNOWLEDGMENTS}

This study was part of the REDFISH EU-funded research project (QLK5-CT1999-01222). We thank Fernando González and Sergio Iglesias (Instituto Español de Oceanografía, Vigo) for allowing us to conduct sampling aboard commercial vessels; José Taranilla, Beatriz Lampón, and Lucía Alonso for collecting the ovaries; and Dolores Domínguez, Alexandre Alonso, Mariña Fabeiro, and Sonia Rábade for counting and measuring the oocytes.

\section{REFERENCES}

Armstrong MJ, Witthames PR. 2012. Developments in understanding of fecundity of fish stocks in relation to egg production methods for estimating spawning stock biomass. Fish. Res. 117/118: 35-47.

Bagenal TB. 1969. The relationship between food supply and fecundity in brown trout Salmo trutta L. J. Fish Biol. 1: 167-182.

Bagenal TB, Braum E. 1978. Eggs and early life history. In: Bagenal TM (ed.), Methods for Assessment of Fish Production in Fresh Waters. IBP Handbook 3: 165-201.

Björnsson H, Sigurdsson TH. 2003. Assessment of golden redfish (Sebastes marinus L) in Icelandic waters. Sci. Mar. 67: 301-314.

Boehlert GW, Barss WH, Lambersson PB. 1982. Fecundity of the widow rockfish, Sebastes entomelas, off the coast of Oregon. Fish. Bull. 80: 881-884.

Bowers MJ. 1992. Annual reproductive cycle of oocytes and embryos of yellowtail rockfish Sebastes flavidus (family Scorpaenidae). Fish. Bull. 90: 231-243.

Bromley PJ, Ravier C, Witthames PR. 2000. The influence of feeding regime on sexual maturation, fecundity and atresia in first-time spawning turbot. J. Fish Biol. 56: 264-278.

Buckley LJ, Smigielski AS, Halavik TA, Caldarone EM, Burns BR, Laurence GC. 1991. Winter flounder Pseudopleuronectes americanus reproductive success. II. Effects of spawning time and female size on size, composition and viability of eggs and larvae. Mar. Ecol. Prog. Ser. 74: 125-135.

Corlett J. 1964. Fecundity of redfish from East Greenland. Annales Biologiques 19, 78 pp.

Drevetnyak KV, Gusev EV. 1996. On fecundity of redfish (Sebastes mentella, Travin) from the Norwegian-Barents Sea population. ICES CM 1996/G: 43.

Fitzhugh GR, Thompson BA, Snider III TG. 1993. Ovarian development, fecundity and spawning frequency of black drum Pogonias cromis in Louisiana. Fish. Bull. 91: 244-253.

Gunderson DR. 1977. Population biology of Pacific Ocean perch, Sebastes alutus, stocks in the Washington-Queen Charlotte Sound region, and their response to fishing. Fish. Bull. 75: 369-403.

Gunderson DR, Callahan P, Goiney B. 1980. Maturation and fecundity of four species of Sebastes. Mar. Fish. Rev. 42: 74-79.

Guraya SS. 1986. The cell and molecular biology of fish oogenesis. Monographs in Developmental Biology 18. Karger, Basel, $223 \mathrm{pp}$.

Haldorson L, Love M. 1991. Maturity and fecundity in the rockfishes, Sebastes spp., a review. Mar. Fish. Rev. 53: 25-31. individuos de la misma talla, casi todas las especies del Pacífico tienen mayores valores de fecundidad que los obtenidos en el presente trabajo. Esto se puede relacionar con la temperatura del agua, ya que la mayoría de las especies del Pacífico estudiadas habitan aguas templadas del Pacífico nororiental al sur de los $55^{\circ}$ de latitud. Sólo Sebastes alutus, la especie que habita aguas más frías y más al norte, mostró valores de fecundidad similares a los de S. mentella. La fecundidad relativa de 23 especies de Sebastes de aguas californianas (MacGregor 1970) fue de dos a ocho veces mayor que en S. mentella. Sin embargo, el diámetro de los ovocitos de las gallinetas del Pacífico (0.6-0.8 $\mathrm{mm}$ en promedio) es considerablemente menor que el de $S$. mentella.

El exponente de la relación entre la fecundidad y la longitud de $S$. mentella fue mayor que 3 , lo cual concuerda con valores previos estimados para S. mentella de otras zonas (St. Pierre y de Lafontaine 1995) y para otras especies de Sebastes de los océanos Pacífico y Atlántico (Corlett 1964, Raitt y Hall 1967, Gunderson 1977, Haldorson y Love 1991). Esto sugiere que la producción total de huevos aumenta notablemente con la proporción de peces de mayor talla en la población desovante, más que con la biomasa de la población desovante (i.e., el potencial reproductivo aumenta con el tamaño de las hembras). Desde hace tiempo se considera inválida la suposición de que la biomasa de la población reproductora es proporcional al potencial reproductivo de la población (Saborido-Rey y Trippel 2013). Se ha estudiado la influencia de atributos maternales en las características reproductivas de diferentes especies mediante diferentes factores, tales como la influencia de la condición (alimentación) en la fecundidad (Kjesbu et al. 1991, Bromley et al. 2000, Kraus et al. 2000) o la influencia de edad/talla y condición en los huevos y características larvales (Hislop 1988, Buckley et al. 1991, Marteinsdottir y Steinarsson 1998, Trippel 1998, Vallin y Nissling 2000, Saborido-Rey et al. 2003). En otras especies, la condición y la talla de las hembras se correlacionan positivamente con el diámetro de los huevos (Kjesbu et al. 1991, Marteinsdottir y Steinarsson 1998, Vallin y Nissling 2000, Marteinsdottir y Begg 2002); sin embargo, en nuestro estudio, el diámetro ovocitario en general no fue influenciado por las características maternales analizadas.

En resumen, en la gallineta nórdica, el peso y la longitud corporal tienen una influencia considerable en la fecundidad, pero no en el diámetro ovocitario. Esto podría ser una estrategia lógica de especies vivíparas, ya que la producción de huevos de mayor tamaño no confiere ninguna ventaja en partícular a las larvas que se desarrollan dentro del ovario, pero invertir la energía excedente en la producción de un mayor número de huevos es claramente una ventaja. Esto explicaría por qué la fecundidad no fue influenciada por la condición en los estados tempranos de desarrollo, pero lo fue en estados posteriores cuando los ovocitos incrementaron considerablemente de tamaño y la fecundidad fue corregida mediante pérdidas atrésicas. Una variación del almacenamiento de 
Hislop JFG. 1988. The influence of maternal length and age on the size and weight of the eggs and the relative fecundity of the haddock, Melanogrammus aeglefinus, in British waters. J. Fish Biol. 32: 923-930.

Hunter JR, Macewicz BJ. 1985. Measurement of spawning frequency in multiple spawning fishes. In: Lasker R (ed.), An Egg Production Method for Estimating Spawning Biomass of Pelagic Fish: Application to the Northern Anchovy, Engraulis mordax. NOAA Tech. Rep. 36: 79-93.

ICES. 2009. Report of the Workshop on Redfish Stock Structure (WKREDS). ICES CM 2009/ACOM:37, 71pp.

ICES. 2014. Report of the North-Western Working Group. ICES CM 2014/ACOM:07, 902 pp.

Jones DH. 1969. Some characteristics of the pelagic redfish (Sebastes mentella Travin) from Weather Station Alfa. J. Cons. Int. Explor. Mer 32: 395-412.

Jones DH. 1970. Food, parasites and the reproductive cycle of pelagic redfish Sebastes mentella Travin from Weather Station Alfa in the North Atlantic. Bull. Mar. Ecol. 6: 347-370.

Kendall A. 2000. An historical review of Sebastes taxonomy and systematics. Mar. Fish. Rev. 62: 1-23.

Kennedy J, Nash RDM, Slotte A, Kjesbu OS. 2011. The role of fecundity regulation and abortive maturation in the reproductive strategy of Norwegian spring-spawning herring (Clupea harengus). Mar. Biol. 158: 1287-1299.

Kjesbu OS. 2009. Applied fish reproductive biology: Contribution of individual reproductive potential to recruitment and fisheries management. In T Jakobsen et al. (eds.), Fish Reproductive Biology: Implications for Assessment and Management. WileyBlackwell, Oxford, UK, pp. 293-332.

Kjesbu OS, Klungsoyr J, Kryvi H, Witthames PR, Greer Walker M. 1991. Fecundity, atresia and egg size of captive Atlantic cod (Gadus morhua) in relation to proximate body composition. Can. J. Fish. Aquat. Sci. 48: 2333-2343.

Koya Y, Hamatsu T, Matsubara T. 1995. Annual reproductive cycle and spawning characteristics of the female kichiji rockfish Sebastolobus macrochir. Fish. Sci. 61: 203-208.

Kraus G. 2002. Variability in egg production of cod (Gadus morhua callarias L.) in the central Baltic Sea. PhD thesis, University of Kiel, Germany, 91 pp.

Kraus G, Müller A, Trella K, Köster FW. 2000. Fecundity of Baltic cod: Temporal and spatial variation. J. Fish Biol. 56: 1327-1341.

Kurita Y, Meier S, Kjesbu OS. 2003. Oocyte growth and fecundity regulation by atresia of Atlantic herring (Clupea harengus) in relation to body condition throughout the maturation cycle. J. Sea Res. 49: 203-219.

Love MS, Johnson K. 1998. Aspects of the life histories of grass rockfish, Sebastes rastrelliger, and brown rockfish, $S$. auriculatus, from Southern California. Fish. Bull. 97: 100-109.

Lowerre-Barbieri SK, Barbieri LR. 1993. A new method of oocyte separation and preservation for fish reproduction studies. Fish. Bull. 91: 165-170.

MacGregor JS. 1970. Fecundity, multiple spawning and description of the gonads in Sebastodes. US Fish and Wildlife Service Special Scientific Report, Fisheries No. 596.

Magnússon J. 1980. On the relation between depth and redfish in spawning condition, SW of Iceland. ICES C.M. 1980/G: 46.

Magnússon J. 1983. The Irminger Sea oceanic stock of redfish; "spawning" and "spawning" area. ICES C.M. 1983/G: 56.

Magnússon J, Magnússon JV. 1995. Oceanic redfish (Sebastes mentella) in the Irminger Sea and adjacent waters. Sci. Mar. 59: 241-254.

Marteinsdottir G, Steinarsson A. 1998. Maternal influence on the size and viability of Iceland cod Gadus morhua eggs and larvae. J. Fish Biol. 52: 1241-1258. energía en el peso corporal podría haber reducido diferencialmente la fecundidad y, por tanto, la mayor correlación observada entre condición, peso y longitud. Dada la importancia de la regulación decreciente en la gallineta nórdica, se requieren más estudios para determinar los mecanismos de atresia folicular y la relación con los atributos de las hembras y la influencia en la fecundidad de las poblaciones.

\section{Agradecimientos}

Este trabajo forma parte del proyecto de investigación denominado REDFISH financiado por la Unión Europea (QLK5-CT1999-01222). Agradecemos a Fernando González y Sergio Iglesias (Instituto Español de Oceanografía, Vigo) el permiso otorgado para realizar muestreos a bordo de embarcaciones comerciales; a José Taranilla, Beatriz Lampón y Lucía Alonso su participacion en la recolección de ovarios; y a Dolores Domínguez, Alexandre Alonso, Mariña Fabeiro y Sonia Rábade su colaboración en el conteo y la medición de ovocitos.

Traducido al español por Christine Harris.

Marteinsdottir G, Begg GA. 2002. Essential relationships incorporating the influence of age, size, and condition on variables required for estimation of reproductive potential in Atlantic cod, Gadus morhua. Mar. Ecol. Prog. Ser. 235: 235-256.

McBride RS, Thurman PE. 2003. Reproductive biology of Hemiramphus brasiliensis and $H$. balao (Hemiramphidae): Maturation, spawning frequency and fecundity. Biol. Bull. 20: 57-67.

Murua H, Saborido-Rey F. 2003. Female reproductive strategies of marine fish species of the North Atlantic. J. Northw. Atl. Fish. Sci. 33: 23-31.

Murua H, Kraus G, Saborido-Rey F, Witthames PR, Thorsen A, Junquera S. 2003. Procedures to estimate fecundity of marine fish species in relation to their reproductive strategy. J. Northw. Atl. Fish. Sci. 33: 33-54.

Óskarsson GJ, Kjesbu OS, Slotte A. 2002. Predictions of realised fecundity and spawning time in Norwegian spring-spawning herring (Clupea harengus). J. Sea Res. 48: 59-79.

R Core Team. 2013. R: A language and environment for statistical computing. R Foundation for Statistical Computing, Vienna, Austria. ISBN 3-900051-07-0, URL: http://www.R-project.org/.

Raitt DFS, Hall WB. 1967. On the fecundity of the redfish. J. Cons. Int. Explor. Mer 31: 237-245.

Rideout RM, Tomkiewicz J. 2011. Skipped spawning in fishes: More common than you might think. Mar. Coast. Fish. 3: 176-189.

Saborido-Rey F. 1994. El género Sebastes Cuvier, 1829 (Pisces, Scorpaenidae) en el Atlántico Norte: identificación de especies y poblaciones mediante métodos morfométricos; crecimiento y reproducción de las poblaciones en Flemish Cap [The genus Sebastes Cuvier 1829 (Pisces, Scorpaenidae) in the North Atlantic: Species and population identification using morphometric techniques; Growth and reproduction of the Flemish Cap populations]. PhD thesis, Universidad Autónoma de Madrid, Spain, 276 pp. http://hdl.handle.net/10261/4391 
Saborido-Rey F, Trippel EA. 2013. Fish reproduction and fisheries. Fish. Res. 138: 1-4.

Saborido-Rey F, Kjesbu OS, Thorsen A. 2003. Buoyancy of Atlantic cod larvae in relation to developmental stage and maternal influences. J. Plankton Res. 25: 291-307.

Saborido-Rey F, Garabana D, Stransky C, Melnikov S, Shibanov V. 2004. Review of the population structure and ecology of Sebastes mentella in the Irminger Sea and adjacent waters. Rev. Fish Biol. Fish. 14: 455-479.

Sigurdsson T, Kristinsson K, Ratz H, Nedreaas K, Melnikov S, Reinert J. 2006. The fishery for pelagic redfish (Sebastes mentella) in the Irminger Sea and adjacent waters. ICES J. Mar. Sci. 63: 725-736.

Sorokin VP. 1961. The redfish gametogenesis and migrations of the Sebastes marinus L. and Sebastes mentella Travin. ICNAF Spec. Publ. 3: 245-250.

St. Pierre JF, de Lafontaine Y. 1995. Fecundity and reproduction characteristics of beaked redfish (Sebastes fasciatus and $S$. mentella) in the Gulf of St. Lawrence. Canadian Technical Report of Fisheries and Aquatic Sciences 2059: 1-32.

Thorsen A, Marshall CT, Kjesbu OS. 2006. Comparison of various potential fecundity models for north-east Arctic cod Gadus morhua L. using oocyte diameter as a standardizing factor. J. Fish Biol. 69: 1709-1730.

Tomkiewicz J, Morgan MJ, Burnett J, Saborido-Rey F. 2003. Available information for estimating reproductive potential of Northwest Atlantic groundfish stocks. J. Northw. Atl. Fish. Sci. 33: $1-21$.

Trippel EA. 1998. Egg size and viability and seasonal offspring production of young Atlantic cod. Trans. Am. Fish. Soc. 127: 339-359.

Vallin L, Nissling A. 2000. Maternal effects on egg size and egg buoyancy of Baltic cod, Gadus mohua: Implications for stock structure effects on recruitment. Fish. Res. 49: 21-37.

Witthames PR, Greenwood LN, Thorsen A, Dominguez R, Murua H, Korta M, Saborido-Rey F, Kjesbu OS. 2009. Advances in methods for determining fecundity: Application of the new methods to some marine fishes. Fish. Bull. 1072: 148-164.

Wootton RJ. 1973. The effect of food ration on egg production in the female three-spined stickleback, Gasterosteus aculeatus L. J. Fish Biol. 5: 89-96.

Wourms JP. 1981. Viviparity: The maternal-fetal relationships in fishes. Am. Zool. 21: 473-515.

Received November 2014, accepted March 2015. 